\title{
Pension Deficits and Corporate Financial Policy: Does Accounting Transparency Matter?
}

\author{
Fani Kalogirou \\ Universidade Católica Portuguesa \\ Católica Lisbon School of Business and Economics \\ 1649-023 Lisbon \\ Portugal \\ Email: f.kalogirou@ucp.pt \\ (Corresponding author) \\ Paraskevi Vicky Kiosse \\ University of Exeter Business School \\ Streatham Court \\ Rennes Drive \\ EX4 4PU Exeter \\ United Kingdom \\ Email: p.kiosse@exeter.ac.uk \\ Peter F. Pope \\ Università Bocconi \\ Via Röntgen 1 \\ 20136 Milano \\ Italy \\ Email: peter.pope@unibocconi.it
}

Acknowledgements: We are grateful to Paul Zarowin (associate editor) and two anonymous reviewers for valuable feedback and suggestions. We also thank Ulf Brüggemann, Stefano Cascino, Mark Clatworthy, Panagiotis Couzoff, Christina Dargenidou, Joanne Horton, Ursa Kosi, Bart Lambrecht, Christian Leuz, Gilad Livne, Tim Marklew, Paul Metcalf, Giovanna Michelon, John O'Hanlon, Per Olsson, Bill Rees, Steven Young and participants at Lancaster University and ESSEC Business School seminars, Varna INTACCT workshop, $27^{\text {th }}$ EAA Doctoral Colloquium, and $34^{\text {th }}$ EAA Annual Congress for helpful comments on previous versions of this paper and Mahmoud El Haj and Azeddine Elhanaoui for providing excellent research assistance in relation to extracting pension disclosures from French annual reports. Paraskevi Vicky Kiosse gratefully acknowledges financial support from Exeter University Business School. Fani Kalogirou gratefully acknowledges the support from FCT Portuguese Foundation of Science and Technology for the project "UID/GES/00407/20013". This work was supported by the EU-funded INTACCT programme - The European IFRS Revolution: Compliance, Consequences and Policy Lessons (Contract No. MRTN-CT-2006-035850). 


\title{
Pension Deficits and Corporate Financial Policy: Does Accounting Transparency Matter?
}

\begin{abstract}
We study changes in financial policies following a regulatory shock to the accounting transparency of defined benefit pension plans. We estimate the hidden pension deficits of French companies subject to mandatory IAS 19 adoption in 2005 using disclosures of early adopters of IAS 19. We find that financially risky companies reporting unexpectedly high pension deficits on first-time IAS 19 adoption subsequently reduce leverage and incur higher cost of debt. Our results suggest that in the absence of transparency the credit market anticipates off-balance sheet pension deficits. However, the introduction of the more transparent IAS 19 regime allows the credit market to correct estimation errors. Our study is one of the first to show that the greater transparency offered by IFRS has negative economic consequences for some companies.
\end{abstract}

$\underline{\text { Keywords: }}$ accounting transparency; defined benefit pension plans; capital structure; offbalance sheet liabilities.

JEL Classification codes: G32; M41 


\section{Introduction}

Defined benefit (DB) pension plan obligations are an economically important form of inside debt that is relevant to the economic decisions of investors and creditors. In this context, Cardinale (2007) and Jin et al. (2006) show that measures of market risk depend on the leverage and risk attributable to unfunded pension deficits, while the results in Rauh (2006) and Campbell et al. (2012) suggest that pension plan funding needs can affect cost of equity and debt, with consequences for corporate investment. Yet despite the significance of DB pension plans, before the adoption of IFRS in 2005 some EU countries did not require pension plan transparency under domestic accounting standards.

In this paper, we examine the debt market consequences of the pension 'news' revealed under IAS 19 Employee Benefits by first time mandatory adopters in 2005 in France. We estimate the pension-related debt of French companies at the time to be on average $21 \%$ of the value of financial debt. ${ }^{1}$ Hence, increased transparency of pension deficits could have an economically significant impact on companies' financial policies. We exploit a feature of French domestic accounting standards before 2005 whereby the early adoption of IAS 19 was allowed and even encouraged but not required, while early adoption of other IFRS was prohibited. This resulted in a substantial number of companies adopting IAS 19 early, before other IFRS were mandated in 2005. We argue that pension deficit information reported by early IAS 19 adopters is relevant to estimating pension deficits for less transparent companies that were later required to adopt IFRS in 2005. We define early adopters as companies that recognize pension deficits or surpluses in accordance with IAS 19 prior to mandatory IFRS adoption in 2005 and we use those early adopters' disclosures to estimate the pension deficit "surprise" for first-time mandatory IFRS adopters in 2005. We then examine the impact of

\footnotetext{
${ }^{1}$ Based on our original sample of non-financial, non-utility companies, before deleting observations for missing non-pension related variables.
} 
expected and unexpected pension deficits on the level, cost, and maturity of debt of mandatory adopters (i.e., companies reporting pension deficits or surpluses under IAS 19 from 2005 onwards).

An extensive body of accounting research has linked accounting transparency to significant capital market benefits for companies, including the cost of equity, the cost of debt and market liquidity (e.g., Botosan, 1997; Sengupta, 1998; Hail, 2002; Yu, 2005; Florou and Kosi, 2015). However, theoretical work suggests that despite these average positive outcomes, mandatory increased transparency should have negative effects for some companies in markets with rational expectations (Johnstone, 2015, 2016; Gao, 2010). We explicitly consider this possibility and predict that the cost of debt will increase and leverage will subsequently be reduced for some companies where increased transparency reveals higher than expected pension deficits.

Consistent with pension liabilities and deficits being credit-relevant, Shivdasani and Stefanescu (2010) and Bartram (2016) report that companies with pension plans have lower financial leverage ratios and Campbell et al. (2012) find that the pension plans' funding needs affect the cost of financing. Despite this evidence there are at least two reasons why increased transparency about DB plan deficits might not have real economic consequences in our setting. First, although the adoption of IAS 19 only became mandatory in 2005, a number of French listed companies adopted IAS 19 early. In those cases, the information transfer and unraveling theories of accounting suggest that markets may be able to evaluate the position of DB plans for less transparent mandatory adopters using relevant information provided by early adopters. Second, when agreeing debt contracts with less transparent companies some lenders are able to obtain information via private communication channels. Still, greater accounting transparency after mandatory adoption may provide new or additional information that allows lenders and creditors to estimate pension deficits more accurately. 
We define pension deficit news (i.e., the unexpected pension deficit) as the difference between actual pension deficits revealed after mandatory IAS 19 adoption and expected pension deficits conditional on information disclosed by voluntary early adopters and company characteristics observable in 2004. Using entropy rebalancing methodology to control for endogenous selection effects of early IAS 19 adoption, we find that increased transparency regarding pension plan deficits is important for the financial policy of high financial risk companies, identified using excess leverage, default probability and credit rating. Financially risky companies with unexpectedly high pension deficits reduce leverage, but low financial risk companies do not. A one standard deviation increase in the unexpected pension deficit increases the cost of debt of financially risky companies by between 189 and 237 basis points. Debt maturity does not change in the short-term, although we find some evidence of change in the mid- to long-term. Importantly, we find that changes in leverage and the cost of debt are associated with the unexpected pension deficit component, but not the expected pension deficit component. The findings are robust to endogeneity and various other sensitivity tests.

In additional analysis, we examine whether companies whose borrowing capacity declines following the adoption of IAS 19 react by reducing shareholders' payout. Our results suggest that financially risky companies do not reduce dividend payout or look to equity investors for additional capital when access to the debt market is restricted. In contrast, low financial risk companies increase net payout to shareholders. These findings are consistent with a transfer of wealth from creditors to shareholders.

We contribute to the literature in a number of ways. First, we extend the accounting literature studying the average positive capital market effects of accounting transparency (e.g., Hail, 2002; Florou and Kosi, 2015; Yu, 2005) by showing that some companies are losing from greater transparency. Focusing specifically on pension disclosures where the level and magnitude of the differences between IFRS and local GAAP are large (Bae et al., 2008), we 
show that enhanced transparency under IFRS has negative debt market consequences for financially risky companies. Second, in doing so, we also contribute to the finance literature examining the relation between pension-related leverage and financial leverage (Shivdasani and Stefanescu, 2010; Bartram, 2016; Campbell et al., 2012). Using mandatory IFRS adoption as an exogenous shock, we show that corporate transparency of pension deficits is an important determinant of corporate financial policy, particularly when companies are financially risky. Our results suggest that the credit market responds to opacity during the pre-IAS 19 period by using pension-related information from early adopters of IAS 19 as well as private information to determine the borrowing capacity of companies. However, the mandated shift to a more transparent disclosure regime provides the credit market with new information and allows prior expectational errors to be corrected thereby facilitating more efficient debt contracting.

Third, by showing that pension deficits reported under IAS 19 are relevant for creditors and affect companies' access to debt markets, our paper also adds to the literatures examining the value and credit relevance of pension disclosures (Landsman, 1986; Barth et al., 1992; Hann et al., 2007) and the economic consequences of recognizing pension plan deficits in financial statements (Anantharaman and Chuk, 2018; Barthelme et al., 2019).

Finally, our evidence that information provided by early adopters of IAS 19 may be useful to the debt market in estimating the pension deficits of less transparent companies sheds light on the potential importance of information transfers and spillovers (Alves et al., 2009; Kim et al., 2008; Shroff et al., 2017). Our findings may have implications for other settings where disclosure has been traditionally opaque.

The remainder of the paper is organized as follows. In Section 2, we discuss relevant literature, describe the setting and develop our hypotheses; in Section 3, we present our research design, sample selection criteria and descriptive statistics; we discuss our results in Section 4; and in Section 5 we conclude. 


\section{Background and Hypotheses Development}

\subsection{Pension Liabilities as Inside Debt}

Corporate DB pension plans can be viewed as a "human resource management tool" for managing employee turnover, increasing employee commitment and regulating retirement behavior (Gustman et al., 1994). Further, because the costs borne by employees are substantial in the event of bankruptcy and companies defaulting on pension obligations, Ippolito (1985) suggests that companies may strategically underfund pension plans to increase employee commitment to the long-term survival of the company. Francis and Reiter (1987) report findings consistent with Ippolito's predictions. An alternative financial perspective recognizes that DB pension plans are also costly to companies because they create inside debt obligations that must be serviced (Peterson, 1994). Prior literature finds that the market views pension assets and liabilities as corporate assets and liabilities (e.g., Landsman, 1986; Barth et al., 1992). In addition, consistent with this pension-related leverage being a source of financial risk, Cardinale (2007) and Jin et al. (2006) report evidence that market risk depends on pension plan leverage and funding status, while Campbell et al. (2012) find that pension plan funding status affects both the cost of debt and the cost of equity of financially constrained companies.

There is also an emerging literature linking pension obligations to various corporate decisions. For instance, Cocco and Volpin (2013) find that UK companies with underfunded pension plans are more likely to use cash when acquiring other companies and they are also less likely to become acquisition targets themselves. Rauh (2006) provides evidence that mandatory contributions to DB pension plans cause capital expenditures to decline, the impact being stronger for companies with a low credit rating. Shivdasani and Stefanescu (2010) estimate that leverage ratios of US companies are on average $35 \%$ higher when pension plan obligations and assets are taken into consideration, indicating that leverage is less conservative than previously thought. They also find that companies with pension plans have lower financial 
leverage ratios. They interpret this result as evidence consistent with the trade-off theory of capital structure, implying that companies choose the level of debt and leverage ratios, after taking pension-related borrowing into account.

\subsection{Accounting Transparency and Market Outcomes}

The mandatory adoption of IAS 19, and more broadly IFRS, is expected to increase transparency (Jeanjean and Stolowy, 2008) and consequently to have important economic consequences for companies (Brüggemann et al., 2013). Lambert et al. (2007) show analytically that, in a forward-looking CAPM world, accounting transparency affects the cost of equity by reducing cash flow uncertainty, captured by the assessed covariance between a company's cash flows with other companies' cash flows, and by changing investors' expectations about the value of future cash flows. Focusing on the effect on cash flow covariances, they demonstrate that increased accounting transparency results in a nondiversifiable reduction in the cost of capital. In line with Lambert et al.'s conclusion, Botosan (1997), Hail (2002), and $\mathrm{Li}$ (2010) find that disclosure levels are negatively related to the cost of equity.

Turning to the credit market, Duffie and Lando (2001) predict that when information about asset values is imperfect, credit spreads and the shape of their term structure should depend on accounting transparency. Yu (2005) provides empirical evidence consistent with Duffie and Lando's predictions, documenting that yield spreads depend on transparency, especially for shorter-maturity debt. Florou and Kosi (2015) show that the introduction of IFRS is associated with greater issuance of public bonds and a reduction in bond yield spreads.

Much of the empirical literature examining accounting transparency effects focuses on the average effects of transparency. However, average effects can mask the possibility that there are both winners and losers when accounting transparency changes. Increased accounting transparency should help eliminate market expectational errors, and such errors may work in 
favor or against individual companies. Consistent with this view, Johnstone $(2015,2016)$ shows that Bayesian updating of expectations in response to enhanced transparency can lead to positive or negative effects on the cost of capital, despite the uncertainty reduction from greater transparency considered by Lambert et al. (2007). Similar conclusions follow if greater accounting transparency affects managerial behavior and investment decisions (Lambert et al., 2007; Gao, 2010). To our knowledge, empirical studies have paid relatively little attention to these theoretical findings suggesting both winners and losers from transparency shocks. ${ }^{2} \mathrm{We}$ explicitly consider this possibility in our empirical analysis.

The accounting transparency of one company can also affect the informational environment of peer companies. The information transfer and unraveling theories of accounting stipulate that investors evaluate a company using information provided by other companies. Foster (1981) is one of the first studies to empirically examine the effect of accounting information not only on the reporting company itself, but also on its industry peers. His results are consistent with information transfers occurring between reporting and nonreporting companies. Many subsequent papers confirm information transfer effects (e.g., Alves et al., 2009; Ramnath, 2002; Shroff et al., 2017) and Kim and Li (2011) and Wang (2014) provide evidence of increased information transfers after the adoption of IFRS.

\subsection{Empirical Setting and Hypotheses Development}

France provides an interesting setting for our analysis for several reasons. First, the French bankruptcy law is extremely creditor unfriendly because it favors the survival of companies and the maintenance of employment over creditors' claims (Gaillot, 2008). Hence, we expect the relevance of pension deficits to creditors to be more pronounced in France than in other more creditor-friendly countries. Second, during our sample period there is no minimum

\footnotetext{
${ }^{2}$ A study showing greater transparency has negative consequences is that by Callahan et al. (2012) who find the mandating of Variable Interest Entities (VIEs) consolidation resulted in an increase in the cost of capital of affected companies.
} 
funding requirement and no routine monitoring or regulation of DB pension plans of French companies. Furthermore, in contrast to some other countries such as the UK and the US, there is no insurance of DB pension plans in France. Given that in France employees are higher in the pecking order than other creditors, we expect credit risk due to the incidence of unfunded pension plan deficits to be more significant in France than in countries where stricter funding requirements and insurance programs are in place. Finally, prior to IFRS French pension accounting rules allowed significant managerial discretion in accounting for pension obligations. In April 2003, Conseil National de la Comptabilite (CNC), i.e., the French National Accounting Authority, recognizing the shortcomings of the French pension accounting standard, published a recommendation encouraging companies to value unfunded pension obligations in accordance with IAS 19 and recognize them in the balance sheet despite the early adoption of other IFRS not being allowed in France. While some companies voluntarily adopted the recommended IAS 19 approach, many companies continued to provide relatively little information on pension obligations in their published financial statements, until they were required to adopt IAS 19 in 2005 (see Online Appendix A for more information on the regulatory setting in France; and Table OA.A1 providing examples of French companies' pension reporting practices pre- and post-IAS 19).

The research setting is summarized in Figure 1. At to, each company decides whether to adopt IAS 19 early when preparing its 2004 financial statements. We do not explicitly model this decision process, but the question of why would all companies not adopt the more transparent reporting under IAS 19 is an important one for our story. Companies choose opacity voluntarily to conceal unfavorable information and/or when the direct disclosure costs or proprietary costs associated with public disclosure are higher than the expected benefits of disclosure. Adoption of IAS 19 certainly poses nontrivial direct implementation costs because estimation of pension liabilities requires (periodic) professional actuarial valuations. Greater 
transparency of pension scheme funding positions under IAS 19 also has the potential to generate proprietary costs by affecting relationships with company employees and labor contracting terms (Ippolito, 1985; Hannan, 2005). Given these considerations, the determinants of the choices made by early adopters of IAS 19 are unclear and our attempts to model the choice failed to reveal significant differences in characteristics between early adopters of IAS 19 and mandatory adopters.

\section{[Insert Figure 1 near here]}

At $t_{1}$, financial policy decisions, including borrowing, dividend policy and new equity issuance decisions occur for all companies. However, while investors and creditors observe the pension disclosures of early IAS 19 adopters, they do not observe the corresponding deficits or surpluses of mandatory adopters who adopt IAS 19 for the first time when required to do so in 2005. The unraveling theory argues that in the absence of direct disclosure costs, markets will discount non-disclosure as a signal of bad news; unless investors are generally uncertain as to whether the provision of information is costly and/or proprietary in nature (Dye, 1985). The possibility that implementation of IAS 19 results in direct or proprietary costs suggests creditors would be uncertain about how to interpret non-adoption. However, rational creditors would not ignore the possibility that there may be hidden leverage due to off-balance sheet pension deficits. We explain below how we model the expected pension deficit using information from early IAS 19 disclosures and other observable company characteristics.

At time $t_{2}$, adoption of IAS 19 becomes mandatory and creditors can now observe actual IAS 19 pension deficits or surpluses for all companies and hence the unexpected component of pension deficits, measured as the difference between the actual pension deficit and the value expected at $\mathrm{t}_{1}$. Creditors react to the information about the unexpected pension deficits at $\mathrm{t}_{3}$. If the information transfer effects from early adopters of IAS 19 enable creditors to accurately estimate the pension deficits of opaque companies in 2004, or if borrowers can credibly and 
accurately communicate their pension deficits via private channels, the mandatory introduction of IAS 19 would have no effect on companies' access to credit markets. On the other hand, if the lack of accounting transparency results in expectational errors and does not allow creditors to accurately identify high pension deficit companies, these companies would benefit from easier access to credit markets prior to mandatory IFRS adoption; in this case, we would expect IAS 19 to have a negative impact on high pension deficit companies' access to credit markets once mandated.

There are at least two different channels that would justify a negative relation between newly revealed pension deficits and the level and/or cost of debt. First, the need to fund the pension deficit in the future will result in negative shocks to expected free cash flow. This in turn constrains companies' ability to invest in positive net present value projects (debt overhang) and leads to more costly external financing (Rauh, 2006; Campbell et al., 2012). Although there were no formal regulatory funding requirements in place at the time of IAS 19 adoption in France, high pension deficits imply that companies will likely have to increase pension contributions to meet future obligations towards plan members. A second possible channel for negative debt market consequences is the potential violation of debt covenants. The increases in balance sheet debt and decreases in net worth can trigger violation of pre-existing covenants. In such cases, companies will need to refinance or restructure debt resulting in lower levels and higher cost of debt (Beneish and Press, 1993; Dichev and Skinner, 2002). Both debt overhang and covenant violation problems are more likely and of greater concern when companies are financially risky - especially when the probability of the face value of debt exceeding the value of the company is high (Rauh, 2006; Campbell et al., 2012; Franzoni, 2009; Dichev and Skinner, 2002; DeFond and Jiambalvo, 1994). Based on the preceding discussion, we develop the following two hypotheses relating to leverage and borrowing costs: 
H1: The change in leverage of mandatory adopters is negatively related to the unexpected pension deficit revealed by IFRS, particularly for financially risky companies.

H2: The change in the cost of borrowing of mandatory adopters is positively related to the unexpected pension deficit revealed by IFRS, particularly for financially risky companies.

To the extent that debt market expectations about the size of mandatory adopters' pension deficit contains estimation error, other debt contract terms such as debt maturity may also be affected by the increased transparency under IFRS. Prior literature suggests that when transparency is low and hence information asymmetry is high (Lang and Lundholm, 2000), companies' debt maturity is the result of a trade-off between liquidity risk and the expected benefits from the resolution of the information asymmetry when transparency increases (e.g., Diamond, 1991). Accordingly, prior to the adoption of IAS 19, companies with unexpectedly high pension deficits could have borrowed more in the long-term to mitigate the risk of being unable to roll-over debt (liquidity risk). To the extent that the adoption of IAS 19 allows debt markets to better identify such companies, we predict that the higher transparency after the adoption of IAS 19 will affect not only the level and cost of financial debt, but also the debt maturity structure. We state our third hypothesis as follows:

H3: The change in debt maturity of mandatory adopters is negatively related to the unexpected pension deficit revealed by IFRS, particularly for financially risky companies. 


\section{Sample and Research Design}

\subsection{Research Design}

We focus on the level of the pension plan deficit as a potential driver of financial policy changes because the funded part of the pension liabilities is secured by the pension plan assets and is thus of little concern to employees or other creditors (S\&P, 2018). We designate companies that voluntarily report information about DB pension obligations under IAS 19 prior to 2005 as early adopters and companies that report under IAS 19 for the first time when IFRS are required in 2005 as mandatory adopters. As discussed earlier, we assume that in the pre-2005 period rational credit market participants mitigate mandatory adopters' non-disclosure of pension obligations and assets using information disclosed by early adopters to form expectations about the then unobservable pension deficits of mandatory adopters. This allows us to decompose the pension plan deficit disclosed on first time mandatory adoption into a Predicted and a Surprise component. We expect that the Predicted component will not be associated with financial policy changes at the time of first-time mandatory adoption, while the Surprise component will be associated with such changes.

We estimate the Predicted and Surprise components of mandatory adopters' pension plan deficits using information for early adopters in 2004 and employing the following regression:

$$
\begin{aligned}
\text { Deficit }_{i}= & \alpha_{0}+\alpha_{1} \text { Age }_{i}+\alpha_{2} \text { Tenure }_{i}+\alpha_{3} \text { Product }_{i}+\alpha_{4} \text { Size }_{i}+\alpha_{5} \text { Cash }_{i}+\alpha_{6} \text { Growth }_{i}+ \\
& \alpha_{7} \text { Profit }_{i}+\alpha_{8} \text { Tax }_{i}+\varepsilon_{i}
\end{aligned}
$$

In equation (1), Deficit is the unfunded pension liability reported by early adopters deflated by total assets in 2004; Age is the number of years that the company exists in the Extel database; ${ }^{3}$ Tenure is the average percentage of employees staying with the same company for more than

\footnotetext{
${ }^{3}$ Age is used as a proxy for the age of the pension plan, in the absence of more specific information to calculate the maturity of pension plans.
} 
10 years $;{ }^{4}$ Product is sales per employee in 2004; Size is the natural logarithm of total assets in 2004; Cash is operating cash flows in 2004 deflated by total assets; Growth is next year's investing cash flows deflated by 2004 total assets and multiplied by minus one; Profit is the ratio of operating income to total assets in 2004; and Tax is calculated as taxes paid in 2004 deflated by 2004 sales. We predict that the coefficients on Age and Size will be positive because pension liabilities tend to be higher for larger, more mature companies. Shivdasani and Stefanescu (2010) suggest that companies in industries relying heavily on human capital offer larger pension plans to reduce employee turnover; hence, we also predict a positive coefficient on Tenure. However, we predict a negative coefficient on Product as highly productive employees might have more negotiation power and a say in the funding of the plan. Following prior literature on the determinants of pension plan funding, we expect the coefficient on Cash and Growth to be positive, the coefficient on Tax to be negative, and we make no specific predictions for Profit as prior results are inconclusive (Shivdasani and Stefanescu, 2010; Francis and Reiter, 1987; and Asthana, 1999).

To the extent that companies, which self-select into early adoption of IAS 19 have different characteristics compared to mandatory adopters, the coefficients estimated from equation (1) might be subject to endogeneity bias and therefore may not be applicable to the mandatory adopters sample. For this reason, when estimating regression (1), we employ an entropy balance matching strategy and reweight the early adopter observations so that the mean of all right-hand side variables of the subsample of early adopters equals the corresponding means of the mandatory adopters subsample, and further that the two subsamples have similar industry representation (Hainmueller, 2012). ${ }^{5}$

\footnotetext{
${ }^{4}$ Source: Institut National de la Statistique et des études économiques, Annule et remplace le $\mathrm{N}^{\circ} 1272$ - Décembre 2009.

${ }^{5}$ Entropy balancing has certain advantages over one-to-one propensity score matching, including a higher degree of covariate balance and the prevention of information loss owing to the retention of all observations (Hainmueller, 2012).
} 
We use estimates of equation (1), derived from the entropy balanced sample of early adopters, to compute the out-of-sample pension deficit of mandatory adopters in 2004 (Predicted). This information is not disclosed until the mandated adoption of IAS 19 and we, therefore, treat the out-of-sample estimates as proxies for creditors' expectations prior to IAS 19 adoption. We then use these estimates to compute the Surprise component defined as the actual pension deficit minus the Predicted pension deficit. We predict that for mandatory adopters the Surprise component of the pension plan deficit is negatively related to the change in leverage and positively related to the change in the cost of debt in the adoption year. We test our main predictions using the following equation:

$$
\begin{aligned}
\Delta \text { Lev }_{i} \text { or } \Delta \text { COost }_{i}= & \beta_{0}+\beta_{1} \text { Surprise }_{i}+\beta_{2} \text { Predicted }_{i}+\beta_{3} \Delta \text { Profit }_{i}+\beta_{4} \Delta \text { Risk }_{i}+\beta_{5} \text { Growth }_{i}+ \\
& \beta_{6} \Delta \text { Tang }_{i}+\beta_{7} \Delta \text { Tax }_{i}+\beta_{8} \text { CrRate }_{i, t-1}+\beta_{9} \text { Lev }_{i, t-1}+\epsilon_{i} .
\end{aligned}
$$

To capture the effects of the initial information shock independent of subsequent company actions in the year of adoption, we focus on the pension plan deficit in the IFRS transition year, i.e., the end of $2004 .^{6}$ In line with our hypotheses, we predict the coefficient of Surprise to be negative (positive) and the coefficient of Predicted to be zero when studying changes in leverage (cost of debt). This would be consistent with creditors using information from other sources to compensate for the lack of transparency from mandatory adopters and estimate their pension plan deficit, but also with the mandatory adoption of IAS 19 providing additional information to creditors, which allows them to correct prior estimation errors.

We define $\Delta L e v$ as leverage in 2005 minus leverage in 2004, where leverage is computed as the sum of long-term and short-term financial debt divided by total assets; and $\triangle D C o s t$ as the borrowing cost in 2005 minus the borrowing cost in 2004, calculated as interest expense

\footnotetext{
${ }^{6}$ Note that in the transition year, mandatory adopters must restate their financial statements from the previous fiscal year (i.e., 2004) to reflect the change in accounting standards.
} 
scaled by average total financial debt. ${ }^{7}$ Prior research suggests that the leverage ratio and borrowing cost are a function of profitability, risk, growth opportunities, liquidation value, tax benefits, and credit rating (see for example Leland, 1994; Kisgen 2006). We, therefore, control for these factors when estimating equation (2). $\Delta$ Profit is the change in return on assets (ROA) between 2004 and 2005, where ROA is defined as operating income divided by total assets; $\triangle R i s k$ is the change in the standard deviation of $R O A$ in the last two consecutive three-year periods; $\Delta$ Growth is the change in the ratio of one-year ahead net investing cash flow over total assets multiplied by minus one; $\Delta$ Tang is the change in the ratio of fixed assets over total assets; $\Delta T a x$ is a proxy for the company's change in the marginal tax-shield benefit, calculated as taxes deflated by sales in $2004 .{ }^{8}$ CrRate $_{t-1}$ is the S\&P company credit rating. ${ }^{9}$ Lastly, Levt-1 is the leverage in 2004, defined as above, and is included in our regression in order to control for potential mean reversion in the leverage ratio.

The predicted signs on the control variables in equation (2) depend on the assumptions about target capital structure. The trade-off theory predicts that profitability, marginal tax rate, and liquidation value are positively related to leverage while risk and growth opportunities are negatively related to leverage. On the other hand, pecking order theory predicts a negative relation between leverage and profitability, risk, and growth, but remains silent about how expected liquidation value and taxes affect leverage. Based on Kisgen (2006), we expect a positive relation between a company's credit rating and leverage changes. Lastly, if leverage is mean-reverting, we expect a negative relation between leverage at the beginning of the period and concurrent changes in leverage.

\footnotetext{
${ }^{7}$ Only a small sub-set of the companies in our sample had traded bonds and hence a meaningful test using market data is not feasible. Thus, we follow prior literature, which in the absence of market data uses this variable to proxy for the corporate cost of debt (see for example Pittman and Fortin, 2004).

${ }^{8}$ We focus on sales in order to proxy for the marginal tax-shield benefit before pension contributions and debt interest.

${ }^{9}$ We thank the anonymous reviewer for suggesting to include this variable.
} 
We test the effect of the transparency shock on debt maturity using the following regression:

$$
\begin{gathered}
\Delta \text { DMat }_{i}=\gamma_{0}+\gamma_{1} \text { Surprise }_{i}+\gamma_{2} \text { Predicted }_{i}+\gamma_{3} \Delta \text { AMat }+\gamma_{4} \Delta \text { Profit }_{i}+\gamma_{5} \Delta \text { Risk }_{i}+ \\
\gamma_{6} \Delta \text { Growth }_{i}+\gamma_{7} \Delta \text { Size }_{i}+\gamma_{8} \text { CrRate }_{i, t-1}+\gamma_{9} \text { DMat }_{i, t-1}+v_{i}
\end{gathered}
$$

where $\triangle D M a t$ is the change in the ratio of long-term financial debt over total financial debt; $\triangle A M a t$ is the change in the maturity of the company's assets, with asset maturity defined as the sum of (Gross PPE / Total Assets) $\times$ (gross PPE / Depreciation Expense) and (Current Assets / Total Assets $) \times($ Current Assets / Cost of Goods Sold) (Datta et al., 2005); 4 Size is the change in the natural logarithm of total assets; and all other variables are defined as above. If companies seek to align the maturity of their assets and liabilities, we expect the coefficient on $\triangle A M a t$ to be positive. Based on results in the prior literature, we expect a positive (negative) relationship between $\triangle D M a t$ and $\Delta$ Profit ( $\triangle$ Risk). We predict the coefficient on $\Delta$ Growth to be negative due to agency costs between debtholders and equity holders (Myers, 1977). According to the framework developed by Datta et al. (2005), we expect the coefficient of $\triangle$ Size to be negative. Lastly, we expect a positive coefficient on CrRate and a negative coefficient on lagged DMat.

We test the effects of transparency on financial policy outcomes using equations (2) and (3), for companies with high and low financial risk separately, defining financial risk with reference to the probability of encountering debt overhang and covenant violation issues. Given the lack of consensus in the prior literature as to how to measure financial risk, we follow Cai and Zhang (2011) and employ measures of excess leverage, financial constraints, and distance to default. First, we distinguish between high and low leverage companies using average industry leverage ratios as cutoff values. Next, following Rauh (2006) and Kisgen (2006), we split the sample based on the sample mean value of the S\&P credit score provided by Capital IQ. Lastly, we split our sample based on the sample mean value of default probability, 
estimated as in Duan et al. (2012) and provided by the Risk Management Institute of the National University of Singapore. ${ }^{10}$

\subsection{Sample Selection}

Our initial sample of 767 observations comprises all companies listed in Euronext Paris in 2005. We then exclude companies whose country of domicile is not France (109), companies that were listed for the first time in 2004 (15) and 2005 (20), companies in the financial sector (102), utilities (7), and companies that did not apply IAS 19 in $2005(43)^{11}$ or that delisted in 2006 (12). The final sample includes 459 company observations in 2005. We hand-collect information on the IFRS pension deficit adjustment from the 2004 and 2005 published annual reports obtained from Thomson One Banker and the links provided on the Euronext official website. Data on pension deficit adjustments are unavailable for 89 companies due to missing annual reports or incomplete reported information, further reducing the sample to 370 companies. ${ }^{12,13}$ Next, we obtain data on accounting variables from the Company Analysis Extel Database which provides as-reported, unadjusted accounting items under both domestic standards and IFRS restatements for 2004. Market data and credit rating data are obtained from Capital IQ. We hand-collect any missing information, when available, from published annual reports. Our final sample consists of 348 companies. We classify companies as "early adopters" when they are explicit that they had applied IAS 19 or CNC recommendation in advance of

\footnotetext{
${ }^{10}$ The results are similar when using industry median or sample mean/median. In addition, the results are similar when using dividend levels and the Whited-Wu index to classify companies. The Whited-Wu index is calculated based on the following model: $-0.091 C F_{i t}-0.062 D I V P O S_{i t}+0.021 T L T D_{i t}-0.044 L N T A_{i t}+0.102 I S G_{i t}-0.053 S G_{i t}$ where $C F_{i t}$ is the ratio of cash flows to total assets, $D I V P O S_{i t}$ is an indicator variable taking the value of 1 if the company pays cash dividend, $T L T D_{i t}$ is the ratio of long-term debt to total assets, $L N T A_{i t}$ is the natural logarithm of total assets, $I S G_{i t}$ is the industry sales growth, and $S G_{i t}$ is the company's sales growth (Whited and Wu, 2006). ${ }^{11}$ This includes companies that do not have DB plans and companies that do not publish consolidated accounts and thus are not required to apply IFRS.

${ }^{12}$ While relevant pension data are available in the Worldscope database, coverage is limited. We therefore handcollect the data required, which results in a larger sample size. For example, the study by Bartram (2016) examining a different research question includes 154 French companies based on a Worldscope sample, whereas we are able to collect data for 348 companies.

${ }^{13}$ Our final sample is statistically similar to the non-financial French listed companies dropped from the sample in terms of leverage ( 0.22 versus 0.21$)$ and total book value of assets ( 2.9 billion versus 2.5 billion). However, the companies in our sample are larger in terms of market capitalization ( 2 billion versus 1.16) and more profitable (0.05 versus 0.03$)$.
} 
mandated IFRS introduction, or if they report zero IFRS pension adjustment in the 2005 firsttime IFRS balance sheet reconciliation statement. Based on these criteria, we classify 177 companies as IAS 19 early adopters ${ }^{14}$ and 171 companies as mandatory adopters.

\subsection{Descriptive Statistics}

The decision to adopt IAS 19 pension accounting early could be a function of direct disclosure costs, proprietary costs, capital market incentives, and the content of the disclosure (see e.g., Scott, 1994; and Leuz, 2003). Table 1 compares descriptive statistics for early IAS 19 adopters and mandatory adopters in the year prior to mandatory adoption. All variables are winsorized at the $1 \%$ extreme percentiles. The leverage ratio (Lev) and cost of debt (DCost) are not statistically different between the two groups when using tests of mean and median differences; however, mandatory adopters have on average less long-term debt (DMat) (52\% versus 55\%), as indicated by the t-test which is albeit only marginally significant. Mandatory adopters also have significantly lower credit ratings (CrRate). Further, mandatory adopters are on average significantly smaller and also marginally significantly more profitable, consistent with fixed disclosure costs creating disincentives for smaller companies to adopt early; and with the possibility that labor negotiation concerns affect the decision to delay the accounting recognition of pension deficits. Lastly, $R \& D$ expenses are significantly higher for early adopters, suggesting that there is greater information asymmetry related to the fundamentals of these companies (Barth et al., 2001). ${ }^{15}$ As can be seen in Table 1, there are no other significant differences between early and mandatory adopters and more importantly, the two groups are not different in terms of the pension plan deficits revealed by mandatory IFRS adoption (Deficit) ${ }^{16}$

\footnotetext{
${ }^{14}$ Of these 177 companies, 123 already reported information under IAS 19 in fiscal year 2003 and the remaining 54 companies were first-time voluntary adopters in 2004.

${ }^{15}$ We replace missing R\&D data with zero, based on the requirement in IAS 38 that companies should report material R\&D expenditure and the discussion in Heitzman et al. (2010).

${ }^{16}$ Unfortunately, even after the mandatory adoption of IAS 19 and the recognition of the pension plan deficit on the balance sheet, many companies continue not to disclose the amount of their projected pension obligation.
} 
Panel A of Table 2 presents the means of all right-hand side variables before and after entropy balancing. As can be seen, the means across the two subsamples become almost identical after the balancing. We present the regression results for our prediction model in Panel B of Table 2. In line with expectations and prior literature, company age (Age) and size (Size) as well as the percentage of employees being with the company for more than 10 years (Tenure) are positively associated with pension plan deficits; while employee productivity (Product) is negatively associated with deficits. The marginal tax-shield benefit (Tax) is negatively associated with plan deficits, consistent with companies timing contributions to their pension plans to optimize taxes, while operating cash flows (Cash), future investing cash flows (Growth) and profitability (Profit) are statistically insignificant. Panel B also reports the univariate comparison of the expected (Predicted) and unexpected (Surprise) components of pension plan deficits for the two subsamples, calculated based on equation (1). Neither Surprise nor Predicted are significantly different across the two subsamples. This suggests that mandatory adopters are not companies with unconditionally higher pension deficits, justifying the use of the information provided by early adopters in estimating markets' expectations of mandatory adopters' deficits.

\section{[Insert Table 2 near here]}

\footnotetext{
Hence, while the net amount is reported there is not always information about gross pension assets and liabilities. We thank an anonymous reviewer for prompting us to clarify this point. For the sub-set of companies providing this information, we find that on average the level of unfunded pension liability relative to the projected benefit obligation (Unfunded\%) is economically and statistically different between mandatory and early adopters. More specifically, our univariate comparison of the two groups suggests that companies with relatively well-funded pension schemes may opt to adopt IAS 19 and disclose information about pension obligations early (0.65 vs 0.73$)$. Alternatively, this difference could be attributed to companies feeling under pressure to better fund their pension plans once they adopt IAS 19.
} 
Table 3 presents descriptive statistics for mandatory adopters in the year of adoption. All variables are winsorized at the $1 \%$ extreme percentiles. The average predicted pension deficit, Predicted, is $1.5 \%$ of total assets. The average unexpected component of the pension plan deficit, Surprise, is relatively small, suggesting that application of the expectations model (1) out-of-sample produces unbiased expectations; the standard deviation of Surprise is 2.7\%, suggesting that the enhanced transparency resulting from IFRS reveals economically material new information about pension plan deficits across the sample.

Sample companies have a median leverage ratio of $21.3 \%$ and on average they appear to reduce their leverage after the mandatory adoption of IAS 19 by $1.3 \%$ of total assets. The average cost of debt in the year of adoption is $5.5 \%$, an average increase of 18 basis points compared to the previous year; and the average credit rating is higher in 2005. In addition, there seems to be no significant change in companies' debt maturity after adoption. The sample companies have an average market-to-book $(M / B)$ ratio of 1.84, ROA (Profit) of 6.7\%, and $17.8 \%$ of their assets are invested in fixed assets (Tang). Even though more than half of the companies do not invest in $R \& D$, some others recognize large $R \& D$ expenses raising the average amount to $2.4 \%$ of total assets. Lastly, sample companies have an average free float of $41.3 \%$ and more than half of them did not raise new equity (EqIssue) or distributed dividends (Div) in the year of adoption. We present descriptive statistics for low and high financial risk mandatory adopters separately in Table OA.B1 of the Online Appendix.

\section{[Insert Table 3 near here]}

Pearson and Spearman correlations among the main regression variables are presented in Table OA.B2 of the Online Appendix. The correlation coefficients, in conjunction with Variance Inflation Factor (VIF) analysis suggest that there are no major multicollinearity concerns. 


\section{Empirical Results and Discussion}

\subsection{Main Results}

Table 4 presents the results for the first hypothesis examining the impact of Predicted and Surprise on changes in the leverage ratio for low and high financial risk companies. Columns (1), (3), and (5) present the results for low financial risk companies; and columns (2), (4), and (6) present the results for high financial risk companies. The results suggest that changes in the leverage ratio are not associated with either the Surprise or Predicted components of pension deficits for low financial risk companies. This result is consistent with findings in Campbell et al. (2012) and suggest that creditors are not concerned about the ability of low financial risk companies to finance their pension plan deficits in the future. On the other hand, the change in leverage is negatively associated with Surprise for financially risky companies, while the Predicted pension deficit is statistically insignificant. The results are similar when we estimate regressions for Surprise and Predicted separately. Overall, the results are consistent with the credit market reacting to unanticipated pension deficits and correcting estimation errors after the increase in pension accounting transparency following the mandatory adoption of IAS 19.

The coefficient on Surprise for risky companies varies between -1.038 and -1.277 , indicating that an unanticipated unfunded pension liability of $1 \%$ of total assets is associated with between $1.04 \%$ and $1.28 \%$ reduction in financial leverage for companies classified as financially risky. This adjustment factor estimate is considerably higher than the $0.36 \%$ average trade-off between pension deficits and financial leverage reported by Shivdasani and Stefanescu (2010). We attribute this difference to three factors. First, unlike Shivdasani and Stefanescu (2010) our focus is on the pension deficit rather than total pension obligations. As noted in Campbell et al. (2012, p. 871), credit rating companies appear to believe "that financing pension liabilities with debt is a credit neutral event" and hence a coefficient close to 1 is to be expected. Second, these results concern financially risky companies where we 
expect the sensitivity of creditors to pension plan deficits to be higher. Lastly, information about mandatory adopters' pension plan deficits not only reveals the amount of incremental net operating debt assumed by companies, but it also signals to the market information about management's type and appetite for risk.

With regards to the control variables, their significance varies across the different regressions, but there is some evidence that changes in profitability and growth are negatively related to leverage changes, consistent with the pecking order theory, and changes in risk are positively related to leverage changes. Leverage ratios seem to be mean-reverting, as suggested by the statistically and economically significant negative coefficient of the lagged leverage ratio.

\section{[Insert Table 4 near here]}

Table 5 reports the results for the second hypothesis examining the impact of the new information about a company's pension deficit on the cost of debt. As shown in columns (1), (3), and (5) of Table 5, neither the expected component of the deficit (Predicted) nor the new information (Surprise) has an impact on the cost of debt of low financial risk companies. On the other hand, consistent with our second hypothesis the coefficient of the Surprise variable is statistically significant for financially risky companies, irrespective of our definition of financial riskiness. More specifically, the coefficient varies between 0.700 and 0.877 , suggesting that a one standard deviation increase of Surprise results in an increase of between 189 and 237 basis points in the cost of debt. Our results are, hence, also economically significant.

\section{[Insert Table 5 near here]}

Based on Diamond (1991), we expect that the introduction of IAS 19 would affect not only the level and cost of financial debt, but also the mix of long-term and short-term debt. In Table 
6 , we test this prediction separately for low and high financial risk companies, as per our third hypothesis. The results suggest that the new accounting standard has no effect on the maturity of corporate debt and the relation is statistically insignificant for all regressions, as indicated by the statistically insignificant coefficient on Surprise. There are at least two plausible explanations for failing to find an effect on maturity structure. Diamond (1991) suggests that debt maturity choices are a trade-off between liquidity risk (risk of not being able to roll over debt) and expected benefits from information asymmetry resolution. Given that in Tables 4 and 5 we find significant results only for financially risky companies, it is quite possible that liquidity risk is high enough for the majority of these companies to outweigh any potential benefit from the resolution of the existing information asymmetry; or that these companies might be restricted by the credit market to raising short-term debt only. Alternatively, it could be that although the cost and level of financial debt can adjust quickly, the debt maturity mix takes longer to adjust to the new information.

To distinguish between these two alternative explanations, in further un-tabulated analysis, we use data from Bloomberg and substitute the ratio of long-term to total debt by the average maturity of actual new debt issues in the period 1/1/2004 - 31/12/2006. Data availability restricts the sample to 59 observations, which significantly reduces the power of our tests. Nonetheless, we find a negative effect of the Surprise component on low financial risk mandatory adopters' maturity of future debt issues, but we find no significant results for financially risky companies. We interpret these findings as providing evidence consistent with both explanations. Namely, we argue that high financial risk companies have already opted for their optimal debt maturity mix before the mandatory adoption of IAS 19 due to the high liquidity risk they are faced with. On the other hand, low financial risk companies' ability and preferences for debt maturity is affected, but the effect takes more than a year to materialize.

\section{[Insert Table 6 near here]}


Overall, our results are consistent with creditors anticipating the pension plan deficits of companies, even when transparency is low, possibly using information from early adopters to compensate for the lack of information by other companies. However, mandatory adoption of IAS 19 reveals relevant and previously unanticipated information and allows creditors to correct their estimation errors. As a result, financially risky companies with unexpectedly high pension deficits reduce their leverage and incur higher costs on their financial debt after the adoption of IAS 19.

\subsection{Additional Analysis}

If the IFRS transparency shock induces changes in leverage, companies' reaction in terms of looking for alternative funding sources is of interest. Accordingly, in Table 7 we study the effect of the newly reported pension deficit information on equity issuance and dividend payout. In Panel A of Table 7, we regress net proceeds from equity offerings (proceeds from issuance minus stock repurchases) on Surprise, Predicted, and a number of control variables suggested by prior literature (see Wang and Welker, 2011). As reported in Panel A of Table 7, columns (2), (4), and (6), we do not find any statistically significant relation between Surprise or Predicted pension plan deficit and equity issuance for financially risky companies. In contrast, for low financial risk companies there is some evidence that Predicted is negatively related to equity issuance (see columns (3) and (5)).

\section{[Insert Table 7 near here]}

Similar results are obtained in Panel B where we examine whether higher transparency affects dividends. Again, there is no evidence suggesting that changes in dividends occur in response to the new pension deficit information for financially risky companies. However, dividend payments for companies with low financial risk increase with the Predicted pension deficit being significantly positive in two out of three models. Note that equity issuance and dividend payout policy is, at least partially, a managerial decision and therefore it is no surprise 
that they appear to be statistically significantly related with the Predicted and not the Surprise component of the pension deficit. Note further, that the general increase in accounting transparency could have resulted in lower information asymmetry and lower dividend payouts in line with the results in Hail et al. (2014). However, we are not studying this average, unconditional effect, but we are rather interested in how the content of the new information has affected shareholders' payout. Overall, the results in Table 7 are consistent with pensionrelated accounting transparency also having an impact on distribution decisions, with low financial risk companies transferring wealth from creditors to shareholders.

\subsection{Robustness Tests and Endogeneity}

It may be possible that private creditors gain access to private information (e.g., Bharath et al., 2008; Dhaliwal et al., 2011) and hence have information on unrecognized pension plan deficits before the mandatory adoption of IAS 19. To test this possibility, we collect data on French listed bonds from Thomson Reuters Eikon and then exclude companies with public debt from the analysis. The results for both the leverage ratio and cost of debt analysis for high financial risk companies reported in Table OA.B3 of the Online Appendix are similar to those presented in Tables 4 and 5 and suggest that it is not companies with public debt issues that drive our results.

Another corporate event which could affect our analysis is the involvement of companies in mergers and acquisitions. Such transactions are often financed by additional debt, and even if they are not, consolidation of additional companies would typically result in a mechanical increase in balance sheet leverage. To ensure that our results are not driven by such changes in the reporting group, we use the Zephyr database to identify companies that either acquired or sold subsidiaries in 2005. We subsequently exclude these companies and repeat our main analysis. The results reported for high financial risk companies in Table OA.B4 of the Online Appendix suggest that our conclusions remain unchanged. If anything, excluding companies 
involved in a merger or acquisition transaction increases both the statistical and economic significance of our main variable of interest, Surprise.

Our ability to distinguish between the Surprise and the Predicted components of the newly recognized pension deficit relies on our prediction model, as presented in Table 2 . If the prediction model is weak then our Predicted variable would be a noisy proxy for market's expectations, and it would not be expected to yield a statistically significant coefficient. In this case, the Surprise variable could become a proxy for the pension deficit's size. To mitigate such concerns, we regress changes in the leverage of mandatory adopters on their ranking in terms of the size of their 2004 pension plan deficit (Ranking). The results for high financial risk firms reported in Table OA.B5 of the Online Appendix indicate that the Ranking variable is insignificant for both changes in the leverage ratio and changes in the cost of borrowing. This provides reassurance that our main results are not driven by the size of the pension deficit, but by the new information provided to creditors (Surprise).

Some of the mandatory adopters in our sample recognized a pension deficit on their balance sheet prior to adoption IFRS, even though they were not complying with the IAS 19 valuation requirements. To confirm that markets' estimation of pension deficit prior to mandatory IAS 19 adoption incorporated information beyond any deficits already recognized by non-early adopting companies, we look at the "total reported surprise" (TRSuprise), the difference between the 2004 recognized pension deficit under local GAAP (if any) and the IFRS adjusted 2004 pension deficit. ${ }^{17}$ In Table OA.B6 of the Online Appendix, we compare the effect of TRSurprise and Surprise on companies' financial policies (columns (1), (2), (4),

\footnotetext{
${ }^{17}$ For example, Carrefour S.A. in its 2004 French GAAP balance sheet recognized a provision for pension liabilities of 179.1 million euro. In its restated 2004 IFRS balance sheet, it recognized a provision for pension liabilities of 732 million euro. In this case, the TRSurprise is $552.9(732-179.1)$ million euro scaled by 2004 French GAAP total assets of 39,000 million euro, equal to $1.4 \%$. Note that our measure of Surprise is equal to $-1.6 \%$ (equivalent to an expected deficit of 1,100 million euro) suggesting that creditors were expecting an even higher IFRS pension deficit, based on the company's characteristics and the information provided by early adopters.
} 
(5), (7), and (8)) for financially risky companies. As can be seen in Panel A of Table OA.B6, while the TRSurprise coefficient is negative in all models, it is not statistically significant. Moving to the cost of debt regressions in Panel B, TRSurprise appears to be positively associated with changes to the cost of debt in two out of the three specifications. However, in all cases using TRSurprise instead of Surprise reduces significantly the model fitness as indicated by the corresponding AIC values - the relative likelihood $\left(e^{\left(A I C_{1}-A I C_{2}\right) / 2}\right)$ varies from 0.00 for companies with excess leverage to 0.08 for companies with a low credit rating. Further, in columns (3), (6), and (9) we break down the TRSurprise variable into the Surprise and a "residual reported surprise" (RRSurprise). Note that in some cases where Surprise is higher than TRSurprise we set RRSurprise equal to zero to avoid reporting negative RRSurprise values when the actual TRSurprise is highly positive. ${ }^{18}$ As reported in columns (3), (6), and (9) of Table OA.B6 of the Online Appendix, while Surprise is statistically significant and consistent with our results in the main analysis, any additional surprise coming from the difference in the reported local GAAP and IFRS numbers (RRSurprise) is statistically equal to zero in all regressions. Overall, these results suggest that non-IAS 19 reported pension numbers can be informative for creditors, but that the IAS 19 pension deficit disclosures provided by early adopters also contain relevant information helpful to the credit market in forming pension deficit expectations for the less transparent mandatory adopters. Our results are consistent with the information transfer literature showing that, when company-specific information is absent or limited, investors use disclosures by peers to improve their understanding of the company (e.g. Kim et al., 2008; Shroff et al., 2017); and Kraft (2015) who finds that accounting numbers

\footnotetext{
${ }^{18}$ Schneider Electric SA is one such case. Schneider Electric SA reported a pension deficit of 660.9 million euro (5.1\% of total assets) in 2004 under French GAAP. In its IFRS adjusted statements however the pension deficit is reported to be 1,030 million euro (7.9\% of total assets). Our prediction model yields an expected (Predicted) pension deficit of 470.8 million euro (3.6\% of total assets). This Predicted value while lower than the reported deficit, it is still significantly higher compared to the industry (sample) average of $1.8 \%(1.5 \%)$. In this scenario, the Surprise variable will take the value of $4.3 \%(7.9 \%-3.6 \%)$ and RRSurprise will take the value of $0 \%$ instead of $-0.8 \%([7.9 \%-5.1 \%]-3.6 \%)$.
} 
adjusted for analysts' assessment of off-balance sheet debt better explain the cost of debt compared to company reported numbers.

Our cross-sectional, first difference specification uses a company as its own control and hence controls for unobservable, time-invariant company heterogeneity. However, as noted in Nikolaev and Van Lent (2005) the results might still be affected by time- and company-varying correlated omitted variables (e.g., IFRS-related information shocks regarding other accounting items). To address this concern, we repeat our main analysis for early adopters. If our results are driven by correlated omitted variables, we would expect to find the same results for early adopters even though both the Surprise and Predicted components of their pension plan deficits are known to the market before the year of our study. The results of the analysis for financially risky early adopters reported in Table OA.B7 of the Online Appendix suggest that our findings for mandatory adopters do not hold for early adopters. This reinforces the argument that it is the change in the way companies accounted for their defined plans that drives our main results.

In addition to the early adopters test, we also re-run our analysis employing a Heckman selection model using the provision of segment-related information in 2004 as our exogenous instrument. Detailed segment disclosures by French companies are quite heterogeneous prior to IFRS adoption and could therefore serve as a good instrument for our purposes, assuming they are not related to the subsequent changes in companies' financial policies, but can capture companies' overall disclosure strategy sufficiently well. The results of the Heckman analysis reported in Table OA.B8 of the Online Appendix are generally consistent with the results reported earlier. The Surprise component is negatively related to changes in the leverage ratio and positively related to changes in the cost of debt in the adoption year for financially risky mandatory adopters; this result holds when we use credit rating and excess leverage to measure financial risk, but not when we use the Merton default probability. Most importantly, however, 
the coefficient of the Inverse Mill Ratio is insignificant in all cases, suggesting that there is no selection bias problem.

\section{Concluding Comments}

In this paper, we examine the impact of accounting transparency about companies' pension deficits on their access to credit. Our analysis suggests that companies with larger than expected pension deficits experience increased cost of debt and reduced leverage when required to report those deficits under IAS 19. This relation is significant only for financially risky companies and for the unexpected component of recognized pension plan deficits. Our analyses indicate that in the absence of transparency the credit market anticipates off-balance sheet pension deficits when setting borrowing constraints, but that the introduction of a more transparent disclosure regime allows the credit market to correct estimation errors with negative consequences for some companies. Overall, our findings suggest that accounting transparency is important to the credit market, and that in the absence of transparency some companies achieve higher levels and lower cost of debt than they would under a more transparent information regime. Our paper extends prior literature on the capital market effects of accounting transparency as well as the finance literature studying the relation between pension obligations and companies' financing. We also contribute to the literature on pension accounting, thereby responding to calls to examine the real effects of disclosure (Kanodia and Sapra, 2016). Finally, our work has implications for other settings where disclosure of offbalance sheet liabilities is opaque. 


\section{References}

Alves, P., Pope, P. F., \& Young, S. (2009). Cross-border information transfers: Evidence from profit warnings issued by European firms. Accounting and Business Research, 39(5), 449472.

Anantharaman, D., \& Chuk, E. (2018). The economic consequences of accounting standards: Evidence from risk-taking in pension plans. The Accounting Review, 93(4), 23-51.

Asthana, S. (1999). Determinants of funding strategies and actuarial choices for defined-benefit pension plans. Contemporary Accounting Research, 16(1), 39-74.

Bae, K.-H., Tan, H., \& Welker, M. (2008). International GAAP differences: The impact on foreign analysts. The Accounting Review, 83(3), 593-628.

Barth, M. E., Beaver, W. H., \& Landsman, W. R. (1992). The market valuation implications of net periodic pension cost components. Journal of Accounting and Economics, 15(1), 2762.

Barth, M. E., Kasznik, R., \& McNichols, M. F. (2001). Analyst coverage and intangible assets. Journal of Accounting Research, 39(1), 1-34.

Barthelme C., Kiosse P. V., \& Sellhorn T. (2019). The impact of accounting standards on pension investment decisions. European Accounting Review, 28(1), 1-33.

Bartram, S. M. (2016). Corporate post-retirement benefit plans and leverage. Review of Finance, 20(2), 575-629.

Beneish, M. D., \& Press, E. (1993). Costs of technical violation of accounting-based debt covenants. The Accounting Review, 66(2), 233-257.

Bharath, S. T., Sunder, J., \& Sunder, S. V. (2008). Accounting quality and debt contracting. The Accounting Review, 83(1), 1-28.

Botosan, C. A. (1997). Disclosure level and the cost of equity capital. The Accounting Review, 72(3), 323-349.

Brüggemann, U., Hitz, J.-M., \& Sellhorn, T. (2013). Intended and unintended consequences of mandatory IFRS adoption: A review of extant evidence and suggestions for future research. European Accounting Review, 22(1), 1-37.

Cai, J., \& Zhang, Z. (2011). Leverage change, debt overhang, and stock prices. Journal of Corporate Finance, 17(3), 391-402.

Callahan, C. M., Smith, R. E., \& Spencer, A. W. (2012). An examination of the cost of capital implications of FIN 46. The Accounting Review, 87(4), 1105-1134.

Campbell, J. L., Dhaliwal, D. S., \& Schwartz, W. C., Jr. (2012). Financing constraints and the cost of capital: Evidence from the funding of corporate pension plans. Review of Financial Studies, 25(3), 868-912.

Cardinale, M. (2007). Corporate pension funding and credit spreads. Financial Analysts Journal, 63(5), 82-101.

Cocco, J. F., \& Volpin, P. F. (2013). Corporate pension plans as takeover deterrents. Journal of Financial and Quantitative Analysis, 48(4), 1119-1144.

Datta, S., Iskandar-Datta, M., \& Raman, K. (2005). Managerial stock ownership and the maturity structure of corporate debt. The Journal of Finance, 60(5), 2333-2350. 
DeFond, M. L., \& Jiambalvo, J. (1994). Debt covenant violation and manipulation of accruals. Journal of Accounting and Economics, 17(1-2), 145-176.

Dhaliwal, D., Hogan, C., Trezevant, R., \& Wilkins, M. (2011). Internal control disclosures, monitoring, and the cost of debt. The Accounting Review, 86(4), 1131-1156.

Diamond, D. (1991). Debt maturity structure and liquidity risk. Quarterly Journal of Economics, 106(3), 709-737.

Dichev, I. D., \& Skinner, D. J. (2002). Large-sample evidence on the debt covenant hypothesis. Journal of Accounting Research, 40(4), 1091-1123.

Duan, J-C., Sun, J., \& Wang, T. (2012). Multiperiod corporate default prediction-A forward intensity approach. Journal of Econometrics, 170, 191-209.

Duffie, D., \& Lando, D. (2001). Term structures of credit spreads with incomplete accounting information. Econometrica, 69(3), 633-664.

Dye, R. A. (1985). Disclosure of nonproprietary information. Journal of Accounting Research, 23(1), 123-145.

Florou, A., \& Kosi, U. (2015). Does mandatory IFRS adoption facilitate debt financing? Review of Accounting Studies, 20(4), 1407-1456.

Foster, G. (1981). Intra-industry information transfers associated with earnings releases. Journal of Accounting and Economics, 3(3), 201-232.

Francis, J. R., \& Reiter, S. A. (1987). Determinants of corporate pension funding strategy. Journal of Accounting and Economics, 9(1), 35-59.

Franzoni, F. (2009). Underinvestment vs. overinvestment: Evidence from price reactions to pension contributions. Journal of Financial Economics, 92, 491-518.

Gaillot, L. (2008). Employees and bankruptcy proceedings - A French perspective. Retrieved from: https://www.iiiglobal.org/sites/default/files/laurentgaillot.pdf.

Gao, P. (2010). Disclosure quality, cost of capital, and investor welfare. The Accounting Review, 85(1), 1-29.

Gustman, A. L., Mitchell, O. S., \& Steinmeier, T. L. (1994). The role of pensions in the labor market: A Survey of the literature. Industrial and Labor Relations Review, 47(3), 417-438.

Hail, L. (2002). The impact of voluntary corporate disclosures on the ex-ante cost of capital for Swiss firms. European Accounting Review, 11(4), 741-773.

Hail, L., Tahoun, A., \& Wang, C. (2014). Dividend payouts and information shocks. Journal of Accounting Research, 52(2), 403-456.

Hainmueller, J. (2012). Entropy balancing for causal effects: A multivariate reweighting method to produce balanced samples in observational studies. Political Analysis, 20(1), 2546.

Hann, R. N., Heflin, F., \& Subramanayam, K. R. (2007). Fair-value pension accounting. Journal of Accounting and Economics, 44(3), 328-358.

Hannan, R. L. (2005). The combined effect of wages and firm profit on employee effort. The Accounting Review, 80(1), 167-188.

Heitzman, S., Wasley, C., \& Zimmerman, J. (2010). The joint effects of materiality thresholds and voluntary disclosure incentives on firms' disclosure decisions. Journal of Accounting and Economics, 49(1-2), 109-132.

Ippolito, R. A. (1985). The economic function of underfunded pension plans. The Journal of Law and Economics, 28(3), 611-651. 
Jeanjean, T., \& Stolowy, H. (2008). Do accounting standards matter? An exploratory analysis of earnings management before and after IFRS adoption. Journal of Accounting and Public Policy, 27, 480-494.

Jin, L., Merton, R. C., \& Bodie, Z. (2006). Do a firm's equity returns reflect the risk of its pension plan? Journal of Financial Economics, 81(1), 1-26.

Johnstone, D. J. (2015). Information and the cost of capital in a mean-variance efficient market. Journal of Business Finance \& Accounting, 42(1-2), 79-100.

Johnstone, D. J. (2016). The effect of information on uncertainty and the cost of capital. Contemporary Accounting Research, 33(2), 752-774.

Kanodia, C., \& Sapra, H. (2016). A real effects perspective to accounting measurement and disclosure: Implications and insights for future research. Journal of Accounting Research, 54(2), 623-676.

Kim, Y., Lacina, M., \& Park, M. S. (2008). Positive and negative information transfers from management forecasts. Journal of Accounting Research, 46(4), 885-908.

Kim, Y., \& Li, S. (2011). The externality effect of accounting standards convergence: Evidence from cross-border information transfers around EU mandatory IFRS adoption. Working Paper.

Kisgen, D. J. (2006). Credit ratings and capital structure. The Journal of Finance, 61(3), 10351072.

Kraft, P. (2015). Rating agency adjustments to GAAP financial statements and their effect on ratings and credit spreads. The Accounting Review, 90(2), 641-674.

Lambert, R., Leuz, C., \& Verrechia, R. E. (2007). Accounting information, disclosure, and the cost of capital. Journal of Accounting Research, 45(2), 385-420.

Landsman, W. R. (1986). An empirical investigation of pension fund property rights. The Accounting Review, 61(4), 662-691.

Lang, M. H., \& Lundholm, R. J. (2000). Voluntary disclosure and equity offerings: Reducing information asymmetry or hyping the stock? Contemporary Accounting Research, 17(4), 623-662.

Leland, H. E. (1994). Corporate debt value, bond covenants, and optimal capital structure. The Journal of Finance, 49(4), 1213-1252.

Leuz, C. (2003). Proprietary versus non-proprietary disclosures: Evidence from Germany. "The Economics and Politics of Accounting: International Perspectives on Research Trends, Policy and Practice", C. Leuz, D. Pfaff, and A. Hopwood (eds), Oxford University Press, 2004, 164-197.

Li, S. (2010). Does mandatory adoption of International Financial Reporting Standards in the European Union reduce the cost of equity capital? The Accounting Review, 85(2), 607-636.

Myers, S. C. (1977). Determinants of corporate borrowing. Journal of Financial Economics, $5(2), 147-175$.

Nikolaev, V., \& Van Lent, L. (2005). The endogeneity bias in the relation between cost-ofdebt capital and corporate disclosure policy. European Accounting Review, 14(4), 677-724.

Peterson, M. A. (1994). Cash flow variability and firm's pension choice: A role for operating leverage. Journal of Financial Economics, 36(3), 361-383.

Pittman, J. A., \& Fortin, S. (2004). Auditor choice and the cost of debt capital for newly public firms. Journal of Accounting and Economics, 37(1), 113-136. 
Ramnath, S. (2002). Investor and analyst reactions to earnings announcements of related firms: An empirical analysis. Journal of Accounting Research, 40(5), 1351-1376.

Rauh, J. D. (2006). Investment and financing constraints: Evidence from the funding of corporate pension plans. The Journal of Finance, 61(1), 33-71.

Scott, T. W. (1994). Incentives and disincentives for financial disclosure: Voluntary disclosure of defined benefit pension plan information by Canadian companies. The Accounting Review, 69(1), 26-43.

Sengupta, P. (1998). Corporate disclosure quality and the cost of debt. The Accounting Review, 73(4), 459-474.

Shivdasani, A., \& Stefanescu, I. (2010). How do pensions affect corporate capital structure decisions? The Review of Financial Studies, 23(3), 1287-1323.

Shroff, N., Verdi, R. S., \& Yost, B. P. (2017). When does the peer information environment matter? Journal of Accounting and Economics, 64(2-3), 183-214.

S\&P (Standards and Poor's) (2018). Corporate methodology: Ratios and adjustments. Retrieved from: http://www.maalot.co.il/publications/MT20131127143756a.pdf.

Wang, C. (2014). Accounting standards harmonization and financial statement comparability: Evidence from transnational information transfer. Journal of Accounting Research, 52(4), 955-992.

Wang, S., \& Welker, M. (2011). Timing equity issuance in response to information asymmetry arising from IFRS adoption in Australia and Europe. Journal of Accounting Research, 49(1), 257-307.

Whited, T. M., \& Wu, G. (2006). Financial constraints risk. The Review of Financial Studies, 19(2), 531-559.

$\mathrm{Yu}, \mathrm{F}$. (2005). Accounting transparency and the term structure of credit spreads. Journal of Financial Economics, 75(1), 53-84. 


\section{Figure 1: Timeline}

Some firms adopt IAS 19

voluntarily while others provide

Mandatory

little/no information about

adoption of

their pension liabilities.

IAS 19 by all.

\begin{tabular}{c|l|l|l}
\hline \multicolumn{1}{|c|}{$\mathrm{t}_{1}$} & \multicolumn{1}{c}{$\mathrm{t}_{3}$} \\
$\mathrm{t}_{0}$ & $\mathrm{t}_{2}$ & \multicolumn{1}{c}{$\begin{array}{c}\text { Debtholders update their } \\
\text { Debtholders learn or form } \\
\text { expectations about corporate } \\
\text { pension liabilities, and debt } \\
\text { contracts are signed. }\end{array}$} & $\begin{array}{l}\text { estimat corporate } \\
\text { pension liabilities and }\end{array}$ \\
& agree on new contracts.
\end{tabular}


Table 1. Early vs. Mandatory Adopters Prior to Mandatory Adoption.

\begin{tabular}{|c|c|c|c|c|c|c|}
\hline & \multicolumn{2}{|c|}{$\underline{\text { Early adopters }}$} & \multicolumn{2}{|c|}{ Mandatory Adopters } & \multirow{2}{*}{$\begin{array}{l}\text { Mean } \\
\text { T-test }\end{array}$} & \multirow{2}{*}{$\begin{array}{c}\text { Wilcoxon } \\
\text { Z-test }\end{array}$} \\
\hline & Mean & P50 & Mean & P50 & & \\
\hline Assets (£M) & 3,740 & 1,500 & 2,040 & 2,200 & 0.04 & 0.57 \\
\hline Age & 11.49 & 10.09 & 11.00 & 11.01 & 0.18 & 0.78 \\
\hline Tenure & 0.425 & 0.481 & 0.421 & 0.480 & 0.35 & 0.56 \\
\hline Product & 0.218 & 0.140 & 0.214 & 0.163 & 0.44 & 0.26 \\
\hline Cash & 0.057 & 0.072 & 0.068 & 0.067 & 0.11 & 0.85 \\
\hline Growth & 0.071 & 0.051 & 0.070 & 0.048 & 0.44 & 0.80 \\
\hline Profit & 0.044 & 0.063 & 0.059 & 0.065 & 0.10 & 0.63 \\
\hline $\operatorname{Tax}$ & 0.018 & 0.014 & 0.020 & 0.017 & 0.17 & 0.18 \\
\hline Deficit & 0.019 & 0.010 & 0.021 & 0.012 & 0.23 & 0.19 \\
\hline Lev & 0.222 & 0.208 & 0.227 & 0.218 & 0.42 & 0.80 \\
\hline$D C o s t$ & 0.061 & 0.044 & 0.054 & 0.044 & 0.31 & 0.88 \\
\hline DMat & 0.552 & 0.617 & 0.519 & 0.512 & 0.10 & 0.26 \\
\hline CrRate & 9.175 & 10.000 & 8.152 & 10.000 & 0.02 & 0.03 \\
\hline Risk & 0.040 & 0.021 & 0.036 & 0.019 & 0.24 & 0.26 \\
\hline Tang & 0.201 & 0.163 & 0.207 & 0.140 & 0.37 & 0.81 \\
\hline AMat & 8.663 & 5.418 & 9.894 & 5.668 & 0.23 & 0.34 \\
\hline EqIssue & 0.016 & 0.000 & 0.017 & 0.000 & 0.49 & 0.83 \\
\hline Div & 0.012 & 0.008 & 0.011 & 0.007 & 0.17 & 0.94 \\
\hline$M / B$ & 1.844 & 1.472 & 1.843 & 1.460 & 0.50 & 0.58 \\
\hline ProfCash & 0.051 & 0.037 & 0.056 & 0.045 & 0.26 & 0.14 \\
\hline$R \& D$ & 0.024 & 0.000 & 0.015 & 0.000 & 0.08 & 0.08 \\
\hline Float & 0.469 & 44.000 & 0.447 & 37.000 & 0.20 & 0.21 \\
\hline
\end{tabular}

Notes: Table 1 provides descriptive statistics comparing early and mandatory adopters in 2004, a year before the mandatory adoption of IAS 19. Assets is total assets as reported on the published consolidated financial statements. Age is the number of years the company appears in the Extel Database. Tenure is the industry average percentage of employees employed for more than 10 years by the same company, as published by the Institut National de la Statistique et des Études Économiques. Product is sales per employee. Cash is operating cash flows deflated by total assets. Growth is next year's investing cash flows deflated by total assets and multiplied by minus one. Profit is the return on operating assets (ROA) defined as operating income over total assets. Tax is taxes paid deflated by sales. Deficit is the difference between the pension obligation and the value of the pension plan assets deflated by total assets. Lev is the ratio of total financial debt over total assets. DCost is the average borrowing cost. DMat is the ratio of long-term financial over total financial debt. CrRate is the company's S\&P credit rating. Risk is the three-year standard deviation of ROA. Tang is defined as the ratio of fixed assets over total assets. AMat is defined as (gross PPE / total assets) $\times$ (gross PPE / depreciation expense) + (current assets / total assets $) \times($ current assets / cost of goods sold). EqIssue is the net proceeds from equity offerings scaled by total assets. Div is total dividend for the year deflated by total assets. $M / B$ is the market value of equity at fiscal year-end divided by the book value of equity. ProfCash is defined as cash balance at the beginning of the year minus net proceeds of equity offering during the previous year scaled by total assets. $R \& D$ is the ratio of investment in research and development activities over total assets. Float is the stocks' free float ratio. 
Table 2. Predicting the Transition Year Pension Plan Deficit of Mandatory Adopters.

Panel A: Entropy Balancing - Means

\begin{tabular}{cccccccc} 
Age & Tenure & Product & Size & Cash & Growth & Profit & Tax \\
\hline \multirow{2}{*}{10.96} & 0.421 & 0.214 & 19.22 & 0.068 & 0.070 & 0.059 & 0.020
\end{tabular}

Mandatory Adopters

11.49

0.425

0.218

19.33

0.057

0.071

0.068

0.070

0.044

0.018

After

10.96

$0.421 \quad 0.214$

19.23

0.059

0.020

Panel B: Prediction Model

\begin{tabular}{|c|c|c|c|c|c|c|c|c|c|}
\hline & Constant & Age & Tenure & Product & Size & Cash & Growth & Profit & $\operatorname{Tax}$ \\
\hline Coefficient & $-0.060 * * *$ & $0.001 * *$ & $0.037 * * *$ & $-0.010 *$ & $0.003 * * *$ & -0.023 & -0.006 & 0.016 & -0.092 * \\
\hline St. error & $(0.013)$ & $(0.000)$ & $(0.013)$ & $(0.006)$ & $(0.001)$ & $(0.019)$ & $(0.012)$ & $(0.017)$ & $(0.052)$ \\
\hline
\end{tabular}

$$
\mathrm{N}=177 ; \mathrm{R}^{2}=0.30
$$

$\begin{array}{lccc} & \text { Early Adopters } & \text { Mandatory Adopters } & \text { p-value } \\ \text { Predicted } & 0.016 & 0.015 & 0.16 \\ \text { Surprise } & 0.003 & 0.006 & 0.13\end{array}$


Notes: Panel A of Table 2 presents the means for all right-hand side variables of regression (1) for mandatory adopters as well as for early adopters before and after the entropy balancing. Panel B of Table 2 presents the results of running regression (1) on the balanced subsample of early adopters and the mean values for the Predicted and Surprise components of companies' pension plan deficit calculated based on this regression. Surprise is the difference between the restated IFRS pension deficit at the beginning of the adoption year and the fitted value from regression 1 (Predicted). Age is the number of years the company appears in the Extel Database. Tenure is the industry average percentage of employees employed for more than 10 years by the same company, as published by the Institut National de la Statistique et des Études Économiques. Product is sales per employee. Size is the natural logarithm of total assets. Cash is operating cash flows deflated by total assets. Growth is next year's investing cash flows deflated by total assets and multiplied by minus one. Profit is the return on operating assets (ROA) defined as operating income over total assets. Tax is taxes paid deflated by sales. Standard errors are reported in parentheses. $* * *, * *, *$ indicate significance at $1 \%, 5 \%$, and $10 \%$ level, respectively. 
Table 3. Descriptive Statistics for Mandatory Adopters in the Year of Adoption.

\begin{tabular}{|c|c|c|c|c|c|c|}
\hline Variables & $\mathbf{N}$ & Mean & St. Dev. & P25 & Median & P75 \\
\hline Surprise & 171 & 0.006 & 0.027 & -0.008 & 0.000 & 0.009 \\
\hline Predicted & 171 & 0.015 & 0.009 & 0.010 & 0.015 & 0.020 \\
\hline$\Delta L e v$ & 171 & -0.013 & 0.064 & -0.041 & -0.008 & 0.022 \\
\hline Lev & 171 & 0.219 & 0.145 & 0.106 & 0.213 & 0.313 \\
\hline$L e v_{t-1}$ & 171 & 0.227 & 0.163 & 0.092 & 0.217 & 0.329 \\
\hline$\Delta D C o s t$ & 171 & 0.002 & 0.047 & -0.010 & 0.000 & 0.007 \\
\hline DCost & 171 & 0.055 & 0.054 & 0.032 & 0.043 & 0.057 \\
\hline${ }_{D C o s} t_{t-1}$ & 171 & 0.054 & 0.063 & 0.033 & 0.044 & 0.058 \\
\hline ADMat & 171 & -0.003 & 0.200 & -0.076 & -0.008 & 0.077 \\
\hline DMat & 171 & 0.518 & 0.279 & 0.314 & 0.553 & 0.742 \\
\hline DMat $_{t-1}$ & 171 & 0.519 & 0.274 & 0.332 & 0.512 & 0.747 \\
\hline CrRate & 171 & 9.152 & 4.213 & 8.000 & 10.000 & 12.000 \\
\hline CrRate $_{t-1}$ & 171 & 8.152 & 4.443 & 6.000 & 10.000 & 11.000 \\
\hline EqIssue & 171 & 0.018 & 0.050 & 0.000 & 0.000 & 0.005 \\
\hline EqIssue $_{\mathrm{t}-1}$ & 171 & 0.017 & 0.044 & 0.000 & 0.000 & 0.004 \\
\hline Div & 171 & 0.014 & 0.028 & 0.000 & 0.000 & 0.018 \\
\hline$D i v_{\mathrm{t}-1}$ & 171 & 0.011 & 0.012 & 0.000 & 0.007 & 0.014 \\
\hline Size & 171 & 19.398 & 1.893 & 18.073 & 19.292 & 20.402 \\
\hline ASize & 171 & 0.101 & 0.192 & 0.020 & 0.065 & 0.155 \\
\hline Profit & 171 & 0.067 & 0.071 & 0.036 & 0.066 & 0.101 \\
\hline AProfit & 171 & 0.008 & 0.065 & -0.012 & 0.002 & 0.018 \\
\hline Risk & 171 & 0.036 & 0.054 & 0.009 & 0.020 & 0.039 \\
\hline$\Delta R i s k$ & 171 & -0.003 & 0.029 & -0.010 & -0.001 & 0.007 \\
\hline Growth & 171 & 0.076 & 0.119 & 0.021 & 0.045 & 0.100 \\
\hline$\Delta$ Growth & 171 & 0.010 & 0.125 & -0.025 & -0.001 & 0.041 \\
\hline Tang & 171 & 0.178 & 0.152 & 0.043 & 0.142 & 0.273 \\
\hline$\Delta$ Tang & 171 & -0.004 & 0.027 & -0.012 & -0.002 & 0.004 \\
\hline Tax & 171 & 0.019 & 0.022 & 0.006 & 0.015 & 0.029 \\
\hline$\Delta T a x$ & 171 & -0.002 & 0.016 & -0.007 & 0.000 & 0.003 \\
\hline AMat & 164 & 9.500 & 13.170 & 2.448 & 5.938 & 10.905 \\
\hline$\Delta A M a t$ & 164 & -0.322 & 7.095 & -0.281 & 0.059 & 0.891 \\
\hline$M / B$ & 171 & 1.839 & 1.346 & 1.061 & 1.459 & 2.090 \\
\hline ProfCash & 171 & 0.092 & 0.104 & 0.029 & 0.068 & 0.123 \\
\hline$R \& D$ & 171 & 0.024 & 0.068 & 0.000 & 0.000 & 0.012 \\
\hline Float & 171 & 0.413 & 0.221 & 0.250 & 0.370 & 0.530 \\
\hline
\end{tabular}


Notes: Table 3 presents descriptive statistics for mandatory adopters for the variables used in the empirical analysis and other company information. Surprise is the difference between the restated IFRS pension deficit at the beginning of the adoption year and the fitted value from regression 1 (Predicted). Lev is the ratio of total financial debt over total assets. DCost is the average borrowing cost. DMat is the ratio of long-term financial over total financial debt. CrRate is the company's S\&P credit rating. EqIssue is the net proceeds from equity offerings scaled by total assets. Div is total dividend for the year deflated by total assets. Size is the natural logarithm of total assets. Profit is the return on operating assets (ROA) defined as operating income over total assets. Risk is the three-year standard deviation of ROA. Growth is next year's investing cash flows deflated by total assets and multiplied by minus one. Tang is defined as the ratio of fixed assets over total assets. Tax is taxes paid deflated by sales. AMat is defined as (gross PPE / total assets) $\times$ (gross PPE / depreciation expense $)+$ (current assets / total assets) $\times$ (current assets / cost of goods sold). $M / B$ is the market value of equity at fiscal year-end divided by the book value of equity. ProfCash is defined as cash balance at the beginning of the year minus net proceeds of equity offering during the previous year scaled by total assets. $R \& D$ is the ratio of investment in research and development activities over total assets. Float is the stocks' free float ratio. 
Table 4. Regression Analysis of Pension Obligation's Impact on Leverage.

\begin{tabular}{|c|c|c|c|c|c|c|}
\hline & \multicolumn{2}{|c|}{ Excess Leverage } & \multicolumn{2}{|c|}{ Credit Rating } & \multicolumn{2}{|c|}{ Merton Default Probability } \\
\hline & $\begin{array}{c}\text { Low Risk } \\
\text { (1) }\end{array}$ & $\begin{array}{c}\text { High Risk } \\
\text { (2) }\end{array}$ & $\begin{array}{c}\text { Low Risk } \\
\text { (3) }\end{array}$ & $\begin{array}{c}\text { High Risk } \\
\text { (4) }\end{array}$ & $\begin{array}{c}\text { Low Risk } \\
\text { (5) }\end{array}$ & $\begin{array}{c}\text { High Risk } \\
\text { (6) }\end{array}$ \\
\hline Constant & $\begin{array}{c}\mathbf{0 . 0 2 7} * * \\
(0.011)\end{array}$ & $\begin{array}{c}0.040 \\
(0.034)\end{array}$ & $\begin{array}{c}0.019 \\
(0.012)\end{array}$ & $\begin{array}{c}\mathbf{0 . 0 5 6}^{*} \\
(0.029)\end{array}$ & $\begin{array}{c}\mathbf{0 . 0 3 1} * * \\
(0.012)\end{array}$ & $\begin{array}{c}0.023 \\
(0.025)\end{array}$ \\
\hline Surprise & $\begin{array}{c}0.139 \\
(0.165)\end{array}$ & $\begin{array}{c}\mathbf{- 1 . 2 7 7 * * *} \\
(0.396)\end{array}$ & $\begin{array}{c}0.166 \\
(0.158)\end{array}$ & $\begin{array}{c}\mathbf{- 1 . 1 6 4} * * \\
(0.450)\end{array}$ & $\begin{array}{c}0.108 \\
(0.175)\end{array}$ & $\begin{array}{c}\mathbf{- 1 . 0 3 8} * * * \\
(0.379)\end{array}$ \\
\hline Predicted & $\begin{array}{l}-0.009 \\
(0.532)\end{array}$ & $\begin{array}{l}-1.096 \\
(0.913)\end{array}$ & $\begin{array}{l}-0.017 \\
(0.454)\end{array}$ & $\begin{array}{l}-1.702 \\
(1.462)\end{array}$ & $\begin{array}{l}-0.253 \\
(0.503)\end{array}$ & $\begin{array}{l}-0.918 \\
(1.054)\end{array}$ \\
\hline AProfit & $\begin{array}{l}-0.142 \\
(0.106)\end{array}$ & $\begin{array}{l}-0.159 \\
(0.110)\end{array}$ & $\begin{array}{c}\mathbf{- 0 . 3 5 1} * * \\
(0.141)\end{array}$ & $\begin{array}{l}-0.095 \\
(0.118)\end{array}$ & $\begin{array}{l}-0.229 \\
(0.146)\end{array}$ & $\begin{array}{l}-0.085 \\
(0.106)\end{array}$ \\
\hline ARisk & $\begin{array}{c}0.100 \\
(0.198)\end{array}$ & $\begin{array}{l}\mathbf{0 . 4 7 9 *} \\
(0.241)\end{array}$ & $\begin{array}{c}0.182 \\
(0.212)\end{array}$ & $\begin{array}{l}\mathbf{0 . 4 3 1} * \\
(0.239)\end{array}$ & $\begin{array}{c}0.164 \\
(0.226)\end{array}$ & $\begin{array}{c}0.323 \\
(0.234)\end{array}$ \\
\hline ATang & $\begin{array}{c}0.291 \\
(0.176)\end{array}$ & $\begin{array}{c}0.004 \\
(0.329)\end{array}$ & $\begin{array}{c}0.130 \\
(0.165)\end{array}$ & $\begin{array}{c}0.513 \\
(0.389)\end{array}$ & $\begin{array}{c}0.056 \\
(0.192)\end{array}$ & $\begin{array}{c}0.399 \\
(0.313)\end{array}$ \\
\hline AGrowth & $\begin{array}{c}-\mathbf{0 . 1 1 3} * * * \\
(0.037)\end{array}$ & $\begin{array}{l}-\mathbf{0 . 1 1 8 *} \\
(0.067)\end{array}$ & $\begin{array}{c}\mathbf{- 0 . 1 2 9} * * * \\
(0.040)\end{array}$ & $\begin{array}{l}-0.010 \\
(0.065)\end{array}$ & $\begin{array}{c}\mathbf{- 0 . 1 0 0} * * * \\
(0.033)\end{array}$ & $\begin{array}{l}-0.104 \\
(0.114)\end{array}$ \\
\hline$\Delta \operatorname{Tax}$ & $\begin{array}{c}0.129 \\
(0.356)\end{array}$ & $\begin{array}{c}0.298 \\
(0.388)\end{array}$ & $\begin{array}{c}0.133 \\
(0.333)\end{array}$ & $\begin{array}{l}\mathbf{0 . 8 8 7} * \\
(0.507)\end{array}$ & $\begin{array}{l}-0.131 \\
(0.316)\end{array}$ & $\begin{array}{c}0.544 \\
(0.479)\end{array}$ \\
\hline CrRate $_{t-1}$ & $\begin{array}{c}0.000 \\
(0.001)\end{array}$ & $\begin{array}{c}0.001 \\
(0.002)\end{array}$ & $\begin{array}{c}0.000 \\
(0.001)\end{array}$ & $\begin{array}{c}0.001 \\
(0.003)\end{array}$ & $\begin{array}{l}-0.000 \\
(0.001)\end{array}$ & $\begin{array}{l}\mathbf{0 . 0 0 4} * \\
(0.002)\end{array}$ \\
\hline $\operatorname{Lev}_{t-1}$ & $\begin{array}{c}-\mathbf{0 . 1 6 8} * * * \\
(0.050)\end{array}$ & $\begin{array}{c}\mathbf{- 0 . 1 7 3} * * * \\
(0.064)\end{array}$ & $\begin{array}{c}\mathbf{- 0 . 1 2 0}^{* * * *} \\
(0.028)\end{array}$ & $\begin{array}{c}\mathbf{- 0 . 1 8 7} * * * \\
(0.059)\end{array}$ & $\begin{array}{c}\mathbf{- 0 . 1 3 9} * * * \\
(0.033)\end{array}$ & $\begin{array}{c}\mathbf{- 0 . 1 8 4} * * * \\
(0.057)\end{array}$ \\
\hline $\mathrm{N}$ & 97 & 74 & 117 & 54 & 109 & 62 \\
\hline $\mathrm{R}^{2}$ & 0.27 & 0.35 & 0.35 & 0.47 & 0.33 & 0.44 \\
\hline
\end{tabular}

Notes: Table 4 presents the results of OLS regressions where the dependent variable is changes in leverage, defined as the ratio of total financial debt over total assets. Surprise is the difference between the restated IFRS pension deficit at the beginning of the adoption year and the fitted value from regression 1 (Predicted). Profit is the return on operating assets (ROA) defined as operating income over total assets. Risk is the three-year standard deviation of ROA. Tang is defined as the ratio of fixed assets over total assets. Growth is next year's investing cash flows deflated by total assets and multiplied by minus one. Tax is taxes paid deflated by sales. CrRate is the company's S\&P credit rating. Lev $t_{t-1}$ is lagged leverage. Standard errors are reported in parentheses. ***, **, * indicate significance at $1 \%, 5 \%$, and $10 \%$ level, respectively. 
Table 5. Regression Analysis of Pension Obligation's Impact on the Cost of Debt.

\begin{tabular}{|c|c|c|c|c|c|c|}
\hline & \multicolumn{2}{|c|}{ Excess Leverage } & \multicolumn{2}{|c|}{ Credit Rating } & \multicolumn{2}{|c|}{ Merton Default Probability } \\
\hline & $\begin{array}{c}\text { Low Risk } \\
\text { (1) } \\
\end{array}$ & $\begin{array}{c}\text { High Risk } \\
\text { (2) }\end{array}$ & $\begin{array}{c}\text { Low Risk } \\
\text { (3) }\end{array}$ & $\begin{array}{c}\text { High Risk } \\
(4) \\
\end{array}$ & $\begin{array}{c}\text { Low Risk } \\
(5)\end{array}$ & $\begin{array}{c}\text { High Risk } \\
\text { (6) }\end{array}$ \\
\hline Constant & $\begin{array}{c}0.017 \\
(0.014)\end{array}$ & $\begin{array}{l}-0.009 \\
(0.010)\end{array}$ & $\begin{array}{l}-0.012 \\
(0.011)\end{array}$ & $\begin{array}{c}\mathbf{0 . 0 4 2} * * \\
(0.019)\end{array}$ & $\begin{array}{c}0.008 \\
(0.013)\end{array}$ & $\begin{array}{l}\mathbf{0 . 0 2 4} * \\
(0.013)\end{array}$ \\
\hline Surprise & $\begin{array}{l}-0.012 \\
(0.208)\end{array}$ & $\begin{array}{c}\mathbf{0 . 8 7 7} * * * \\
(0.119)\end{array}$ & $\begin{array}{c}0.158 \\
(0.150)\end{array}$ & $\begin{array}{c}\mathbf{0 . 7 0 0}^{* * *} \\
(0.295)\end{array}$ & $\begin{array}{c}0.012 \\
(0.189)\end{array}$ & $\begin{array}{c}\mathbf{0 . 7 6 4} * * * \\
(0.198)\end{array}$ \\
\hline Predicted & $\begin{array}{c}0.090 \\
(0.671)\end{array}$ & $\begin{array}{c}0.027 \\
(0.274)\end{array}$ & $\begin{array}{c}0.546 \\
(0.430)\end{array}$ & $\begin{array}{c}0.699 \\
(0.960)\end{array}$ & $\begin{array}{c}0.149 \\
(0.543)\end{array}$ & $\begin{array}{l}-0.357 \\
(0.552)\end{array}$ \\
\hline$\Delta$ Profit & $\begin{array}{c}\mathbf{0 . 3 0 5} * * \\
(0.134)\end{array}$ & $\begin{array}{l}-0.042 \\
(0.033)\end{array}$ & $\begin{array}{l}-0.060 \\
(0.133)\end{array}$ & $\begin{array}{c}0.043 \\
(0.077)\end{array}$ & $\begin{array}{l}\text { 0.291* } \\
(0.157)\end{array}$ & $\begin{array}{l}-0.055 \\
(0.056)\end{array}$ \\
\hline ARisk & $\begin{array}{l}\mathbf{0 . 4 5 7 *} \\
(0.249)\end{array}$ & $\begin{array}{c}0.009 \\
(0.072)\end{array}$ & $\begin{array}{c}0.044 \\
(0.201)\end{array}$ & $\begin{array}{c}0.188 \\
(0.157)\end{array}$ & $\begin{array}{c}0.191 \\
(0.243)\end{array}$ & $\begin{array}{l}\mathbf{0 . 2 4 6 *} \\
(0.122)\end{array}$ \\
\hline STang & $\begin{array}{l}-0.281 \\
(0.222)\end{array}$ & $\begin{array}{l}-0.085 \\
(0.099)\end{array}$ & $\begin{array}{l}-0.194 \\
(0.156)\end{array}$ & $\begin{array}{l}-0.202 \\
(0.255)\end{array}$ & $\begin{array}{l}-0.263 \\
(0.207)\end{array}$ & $\begin{array}{l}-0.134 \\
(0.164)\end{array}$ \\
\hline AGrowth & $\begin{array}{l}-0.051 \\
(0.047)\end{array}$ & $\begin{array}{l}-0.011 \\
(0.020)\end{array}$ & $\begin{array}{c}\mathbf{- 0 . 0 9 0} * * \\
(0.037)\end{array}$ & $\begin{array}{c}0.057 \\
(0.043)\end{array}$ & $\begin{array}{l}-0.042 \\
(0.035)\end{array}$ & $\begin{array}{c}0.040 \\
(0.060)\end{array}$ \\
\hline$\Delta \operatorname{Tax}$ & $\begin{array}{l}\mathbf{- 0 . 8 5 0} * \\
(0.450)\end{array}$ & $\begin{array}{c}\mathbf{- 0 . 3 4 9} * * * \\
(0.116)\end{array}$ & $\begin{array}{c}0.014 \\
(0.315)\end{array}$ & $\begin{array}{c}-\mathbf{0 . 8 0 8} * * \\
(0.333)\end{array}$ & $\begin{array}{l}-0.454 \\
(0.341)\end{array}$ & $\begin{array}{l}-\mathbf{0 . 4 5 3} * \\
(0.251)\end{array}$ \\
\hline CrRate $_{t-1}$ & $\begin{array}{c}\mathbf{- 0 . 0 0 3} * * \\
(0.001)\end{array}$ & $\begin{array}{c}0.000 \\
(0.001)\end{array}$ & $\begin{array}{l}-\mathbf{- 0 . 0 0 2} * \\
(0.001)\end{array}$ & $\begin{array}{l}-0.002 \\
(0.002)\end{array}$ & $\begin{array}{c}-\mathbf{- 0 . 0 0 2} * * \\
(0.001)\end{array}$ & $\begin{array}{l}-\mathbf{- 0 . 0 0 2} * \\
(0.001)\end{array}$ \\
\hline $\operatorname{Lev}_{t-1}$ & $\begin{array}{c}0.029 \\
(0.063)\end{array}$ & $\begin{array}{c}0.022 \\
(0.019)\end{array}$ & $\begin{array}{l}\mathbf{0 . 0 4 4} * \\
(0.027)\end{array}$ & $\begin{array}{c}-\mathbf{0 . 0 9 8} * * \\
(0.039)\end{array}$ & $\begin{array}{c}0.021 \\
(0.035)\end{array}$ & $\begin{array}{l}-0.009 \\
(0.030)\end{array}$ \\
\hline $\mathrm{N}$ & 97 & 74 & 117 & 54 & 109 & 62 \\
\hline $\mathrm{R}^{2}$ & 0.19 & 0.56 & 0.17 & 0.36 & 0.12 & 0.39 \\
\hline
\end{tabular}

Notes: Table 5 presents the results of OLS regressions where the dependent variable is changes in the cost of borrowing. Surprise is the difference between the restated IFRS pension deficit at the beginning of the adoption year and the fitted value from regression 1 (Predicted). Profit is the return on operating assets (ROA) defined as operating income over total assets. Risk is the three-year standard deviation of ROA. Tang is defined as the ratio of fixed assets over total assets. Growth is next year's investing cash flows deflated by total assets and multiplied by minus one. Tax is taxes paid deflated by sales. CrRate is the company's S\&P credit rating. Levt-l is lagged leverage. Standard errors are reported in parentheses. $* * *, * *, *$ indicate significance at $1 \%, 5 \%$, and $10 \%$ level, respectively. 
Table 6. Regression Analysis of Pension Obligation's Impact on Debt Maturity.

\begin{tabular}{|c|c|c|c|c|c|c|}
\hline & \multicolumn{2}{|c|}{ Excess Leverage } & \multicolumn{2}{|c|}{ Credit Rating } & \multicolumn{2}{|c|}{ Merton Default Probability } \\
\hline & $\begin{array}{c}\text { Low Risk } \\
\text { (1) }\end{array}$ & $\begin{array}{c}\text { High Risk } \\
\text { (2) }\end{array}$ & $\begin{array}{c}\text { Low Risk } \\
\text { (3) }\end{array}$ & $\begin{array}{c}\text { High Risk } \\
\text { (4) }\end{array}$ & $\begin{array}{c}\text { Low Risk } \\
\text { (5) }\end{array}$ & $\begin{array}{c}\text { High Risk } \\
\text { (6) }\end{array}$ \\
\hline Constant & $\begin{array}{c}\mathbf{0 . 1 0 7} * \\
(0.056)\end{array}$ & $\begin{array}{c}\mathbf{0 . 1 3 9} * \\
(0.080)\end{array}$ & $\begin{array}{c}0.084 \\
(0.062)\end{array}$ & $\begin{array}{c}\mathbf{0 . 2 8 7} * * * \\
(0.094)\end{array}$ & $\begin{array}{c}\mathbf{0 . 1 2 1} * \\
(0.066)\end{array}$ & $\begin{array}{c}\mathbf{0 . 0 9 7} * \\
(0.057)\end{array}$ \\
\hline Surprise & $\begin{array}{c}0.556 \\
(0.681)\end{array}$ & $\begin{array}{c}0.712 \\
(1.366)\end{array}$ & $\begin{array}{c}0.157 \\
(0.647)\end{array}$ & $\begin{array}{l}-0.313 \\
(1.617)\end{array}$ & $\begin{array}{l}-0.094 \\
(0.732)\end{array}$ & $\begin{array}{l}-0.342 \\
(0.927)\end{array}$ \\
\hline Predicted & $\begin{array}{c}0.518 \\
(2.213)\end{array}$ & $\begin{array}{l}-0.842 \\
(2.376)\end{array}$ & $\begin{array}{c}1.079 \\
(2.083)\end{array}$ & $\begin{array}{l}-4.319 \\
(4.007)\end{array}$ & $\begin{array}{c}1.889 \\
(2.360)\end{array}$ & $\begin{array}{l}-0.396 \\
(1.996)\end{array}$ \\
\hline$\Delta A M a t$ & $\begin{array}{c}0.003 \\
(0.005)\end{array}$ & $\begin{array}{c}0.003 \\
(0.003)\end{array}$ & $\begin{array}{l}-0.003 \\
(0.005)\end{array}$ & $\begin{array}{c}0.004 \\
(0.004)\end{array}$ & $\begin{array}{c}0.003 \\
(0.004)\end{array}$ & $\begin{array}{l}-0.002 \\
(0.003)\end{array}$ \\
\hline AProfit & $\begin{array}{l}-0.584 \\
(0.467)\end{array}$ & $\begin{array}{l}\mathbf{0 . 5 1 3} * \\
(0.285)\end{array}$ & $\begin{array}{l}-0.005 \\
(0.566)\end{array}$ & $\begin{array}{l}-0.065 \\
(0.339)\end{array}$ & $\begin{array}{l}-\mathbf{1 . 3 3 8 *} \\
(0.716)\end{array}$ & $\begin{array}{l}\text { 0.359* } \\
(0.209)\end{array}$ \\
\hline ARisk & $\begin{array}{c}1.371 \\
(0.875)\end{array}$ & $\begin{array}{l}-0.826 \\
(0.759)\end{array}$ & $\begin{array}{c}0.361 \\
(0.972)\end{array}$ & $\begin{array}{l}\mathbf{1 . 5 3 4} * \\
(0.790)\end{array}$ & $\begin{array}{c}0.311 \\
(1.017)\end{array}$ & $\begin{array}{l}-0.043 \\
(0.577)\end{array}$ \\
\hline AGrowth & $\begin{array}{l}-0.075 \\
(0.190)\end{array}$ & $\begin{array}{c}\mathbf{- 0 . 4 4 1} * * \\
(0.184)\end{array}$ & $\begin{array}{l}-0.287 \\
(0.196)\end{array}$ & $\begin{array}{l}\mathbf{- 0 . 4 1 4 *} \\
(0.206)\end{array}$ & $\begin{array}{l}\mathbf{- 0 . 3 0 8 *} \\
(0.161)\end{array}$ & $\begin{array}{l}-0.166 \\
(0.253)\end{array}$ \\
\hline ASize & $\begin{array}{l}\text { 0.225* } \\
(0.122)\end{array}$ & $\begin{array}{c}\mathbf{- 0 . 2 8 4} * * \\
(0.118)\end{array}$ & $\begin{array}{c}0.090 \\
(0.128)\end{array}$ & $\begin{array}{l}-0.082 \\
(0.142)\end{array}$ & $\begin{array}{c}0.140 \\
(0.135)\end{array}$ & $\begin{array}{c}\mathbf{- 0 . 2 3 9} * * \\
(0.100)\end{array}$ \\
\hline CrRate $_{t-1}$ & $\begin{array}{l}-0.000 \\
(0.004)\end{array}$ & $\begin{array}{c}0.003 \\
(0.005)\end{array}$ & $\begin{array}{c}0.004 \\
(0.004)\end{array}$ & $\begin{array}{l}-0.007 \\
(0.008)\end{array}$ & $\begin{array}{c}0.002 \\
(0.004)\end{array}$ & $\begin{array}{l}-0.002 \\
(0.005)\end{array}$ \\
\hline$D_{M a t} t_{t-1}$ & $\begin{array}{c}\mathbf{- 0 . 3 0 9} * * * \\
(0.071)\end{array}$ & $\begin{array}{c}\mathbf{- 0 . 2 2 1} * * \\
(0.090)\end{array}$ & $\begin{array}{c}-\mathbf{0 . 2 8 6} \\
(0.074)\end{array}$ & $\begin{array}{c}\mathbf{- 0 . 3 5 4} * * * \\
(0.097)\end{array}$ & $\begin{array}{c}-\mathbf{0 . 3 5 1} * * * \\
(0.074)\end{array}$ & $\begin{array}{l}-0.113 \\
(0.075)\end{array}$ \\
\hline $\mathrm{N}$ & 96 & 68 & 112 & 52 & 105 & 59 \\
\hline $\mathrm{R}^{2}$ & 0.31 & 0.27 & 0.17 & 0.32 & 0.31 & 0.23 \\
\hline
\end{tabular}

Notes: Table 6 presents the results of OLS regressions where the dependent variable is changes in debt maturity, defined as the ratio of long-term financial over total financial debt. Surprise is the difference between the restated IFRS pension deficit at the beginning of the adoption year and the fitted value from regression 1 (Predicted). AMat is defined as (gross PPE / total assets) $\times$ (gross PPE / depreciation expense) + (current assets / total assets) $\times$ (current assets / cost of goods sold). Profit is the return on operating assets (ROA) defined as operating income over total assets. Risk is the three-year standard deviation of ROA. Growth is next year's investing cash flows deflated by total assets and multiplied by minus one. Size is the natural logarithm of total assets. CrRate is the company's $\mathrm{S} \& \mathrm{P}$ credit rating. DMat is the ratio of long-term financial over total financial debt. Standard errors are reported in parentheses. ***, $* *, *$ indicate significance at $1 \%, 5 \%$, and $10 \%$ level, respectively. 
Table 7. Regression Analysis of the Pension Obligation's Impact on Shareholder Payout.

Panel A: Equity Issuance (EqIssue)

Excess Leverage

\begin{tabular}{|c|c|}
\hline $\begin{array}{c}\text { Low Risk } \\
\text { (1) }\end{array}$ & $\begin{array}{c}\text { High Risk } \\
\text { (2) }\end{array}$ \\
\hline 0.056 & -0.086 \\
\hline$(0.055)$ & $(0.091)$ \\
\hline-0.008 & 0.153 \\
\hline$(0.117)$ & $(0.317)$ \\
\hline
\end{tabular}

Predicted

Profit

Risk

Growth

Tang

Issue $_{t-1}$

Size

$M / B$

ProfCash

$R \& D$

Float
$-0.187$

$(0.627)$

$-1.313$

(1.115)

$-0.171$

(0.108)

0.074

(0.138)

$(0.075)$

0.044*

(0.026)

$-0.001$

(0.022)

0.024

(0.091)

$-0.003$

(0.003)

0.006*

(0.003)

$-0.050$

(0.033)

$0.166 * *$

(0.066)

0.000

(0.000)
0.119 **

(0.051)

$-0.037$

(0.041)

0.296

(0.192)

0.007

(0.005)

0.008

(0.007)

$-0.025$

(0.127)

0.176*

(0.102)

$-0.001$

(0.000)
Credit Rating

Low Risk High Risk

$\frac{(3)}{-0.017}$

(0.058)

$-0.025$

(0.135)

-1.638 **

(0.695)

$-0.037$

(0.070)

0.029

(0.119)

0.058*

(0.032)

$-0.019$

(0.021)

$-0.071$

(0.118)

0.003

(0.003)

0.002

(0.004)

$-0.053$

(0.046)

$0.162^{* * *}$

$(0.065)$

0.000

(0.000)

\begin{tabular}{c}
$(\mathbf{4})$ \\
\hline-0.088 \\
$(0.133)$ \\
0.077 \\
$(0.347)$
\end{tabular}

0.104

(1.246)

$-0.026$

(0.081)

0.022

(0.121)

0.103**

(0.048)

$-0.033$

(0.063)

0.314*

(0.180)

0.006

(0.008)

$-0.011$

(0.010)

$-0.044$

(0.079)

$0.484 * * *$

(0.133)

$-0.000$

(0.000)

No Obs.

97

74

117

0.41

0.19

0.25

R-sq

Merton Default Probability

\begin{tabular}{ccc}
\hline $\begin{array}{c}\text { Low Risk } \\
(\mathbf{5})\end{array}$ & & $\begin{array}{c}\text { High Risk } \\
(\mathbf{6})\end{array}$ \\
\cline { 1 - 1 }-0.002 & & 0.023 \\
$(0.063)$ & & $(0.101)$ \\
0.035 & & -0.151 \\
$(0.142)$ & & $(0.316)$ \\
$\mathbf{- 1 . 3 9 4 *}$ & & -0.712 \\
$(0.741)$ & & $(1.131)$ \\
$\mathbf{- 0 . 1 5 0 * *}$ & & -0.016 \\
$(0.062)$ & & $(0.107)$ \\
0.049 & & -0.037 \\
$(0.147)$ & & $(0.106)$
\end{tabular}

$\mathbf{0 . 0 7 6}^{* * *}$

0.034

(0.026)

(0.087)

$-0.017$

$-0.013$

(0.024)

(0.045)

0.054

0.273*

(0.157)

(0.147)

0.002

$-0.001$

(0.004)

(0.006)

0.004

0.003

(0.004)

(0.009)

$-0.091 * *$

0.047

(0.044)

(0.087)

0.161**

0.329****

$(0.081)$

(0.092)

0.000

$-0.000$

54

(0.000)

$(0.000)$

0.48

109

62

0.24 
Panel B: Dividend Payout (Div)

Excess Leverage

\begin{tabular}{|c|c|c|c|c|c|c|}
\hline & & & \\
\hline & $\begin{array}{c}\text { Low Risk } \\
\text { (1) }\end{array}$ & $\begin{array}{c}\text { High Risk } \\
\text { (2) }\end{array}$ & $\begin{array}{c}\text { Low Risk } \\
\text { (3) }\end{array}$ & $\begin{array}{c}\text { High Risk } \\
(4)\end{array}$ & $\begin{array}{c}\text { Low Risk } \\
(5)\end{array}$ & $\begin{array}{c}\text { High Risk } \\
\text { (6) }\end{array}$ \\
\hline \multirow[t]{2}{*}{ Constant } & 0.003 & 0.001 & -0.007 & 0.001 & -0.001 & 0.005 \\
\hline & $(0.007)$ & (0.006) & $(0.007)$ & $(0.007)$ & (0.009) & $(0.003)$ \\
\hline \multirow[t]{2}{*}{ Surprise } & 0.098 & -0.070 & 0.097 & -0.034 & 0.123 & -0.027 \\
\hline & (0.107) & $(0.111)$ & $(0.085)$ & $(0.160)$ & (0.113) & (0.069) \\
\hline \multirow[t]{2}{*}{ Predicted } & 0.522 & 0.374 & $0.515^{*}$ & 0.265 & $0.700 *$ & 0.021 \\
\hline & $(0.346)$ & $(0.274)$ & $(0.265)$ & $(0.464)$ & $(0.358)$ & $(0.178)$ \\
\hline \multirow[t]{2}{*}{ Profit } & $0.084^{* *}$ & -0.004 & $0.155 * * *$ & 0.011 & $0.082 *$ & -0.023 \\
\hline & $(0.037)$ & $(0.035)$ & $(0.045)$ & $(0.036)$ & $(0.046)$ & $(0.022)$ \\
\hline \multirow[t]{2}{*}{$\operatorname{Div}_{t-1}$} & -0.080 & $0.554^{*}$ & -0.219 & $1.524 * * *$ & -0.069 & 0.316 \\
\hline & $(0.209)$ & $(0.314)$ & $(0.169)$ & $(0.466)$ & $(0.214)$ & $(0.208)$ \\
\hline No Obs. & 97 & 74 & 117 & 54 & 109 & 62 \\
\hline R-sq & 0.08 & 0.09 & 0.12 & 0.21 & 0.06 & 0.06 \\
\hline
\end{tabular}

Notes: Table 7 examines how the change in leverage has been achieved. The dependent variables are equity issuance (Panel A) and dividend payout (Panel B). Equity Issuance (EqIssue) is the adoption year net proceeds from equity offerings scaled by total assets at the beginning of the year. Dividend Payout (Div) is the total amount of dividend in the adoption year scaled by total assets at the beginning of the year. Surprise is the difference between the restated IFRS pension deficit at the beginning of the adoption year and the fitted value from regression 1 (Predicted). Profit is the return on operating assets (ROA) defined as operating income over total assets. Risk is the three-year standard deviation of ROA. Growth is next year's investing cash flows deflated by total assets and multiplied by minus one. Tang is defined as the ratio of fixed assets over total assets. Size is the natural logarithm of total assets. $M / B$ is the market value of equity at fiscal year-end divided by the book value of equity. ProfCash is defined as cash balance at the beginning of the year minus net proceeds of equity offering during the previous year scaled by total assets. $R \& D$ is the ratio of investment in research and development activities over total assets. Float is the stocks' free float ratio. Standard errors are reported in parentheses. $* * * * *, *$ indicate significance at $1 \%, 5 \%$, and $10 \%$ level, respectively. 


\title{
Online Supplemental Materials to "Pension Deficits and Corporate Financial
} Policy: Does Accounting Transparency Matter?"

\author{
Fani Kalogirou \\ Universidade Católica Portuguesa \\ Católica Lisbon School of Business and Economics \\ Lisbon, Portugal \\ Email: f.kalogirou@ucp.pt \\ (Corresponding author) \\ Paraskevi Vicky Kiosse \\ University of Exeter Business School \\ Exeter, United Kingdom \\ Email:p.kiosse@exeter.ac.uk \\ Peter F. Pope \\ Università Bocconi \\ Milano, Italy \\ Email: peter.pope@unibocconi.it
}


Table of Contents

Appendix A - Regulatory Setting and Pension Disclosures in France

The French Regulatory Setting

Table OA.A1: Corporate Pension Disclosures: Early vs Mandatory Adopters

Example 1: Carrefour

Example 2: ORPEA

Example 3: L'Oréal

Appendix B - Additional Analysis

Table OA.B1: Descriptive Statistics for Mandatory Adopters in the Year of Adoption

Table OA.B2: Correlation Matrix

Table OA.B3: Regression Analysis of Pension Obligation's Impact on Debt - Excluding Companies with Public Debt

Table OA.B4: Regression Analysis of Pension Obligation's Impact on Debt - Excluding Companies Involved in M\&As

Table OA.B5: Regression Analysis of Pension Obligation's Impact on Leverage Ranking

Table OA.B6: Regression Analysis of Pension Obligation's Impact on Debt - Reported Adjustment

Table OA.B7: Regression Analysis of Pension Obligation's Impact on Debt - Early Adopters

Table OA.B8: Regression Analysis of Pension Obligation's Impact on Leverage Heckman Selection Model

References 


\section{Appendix A - Regulatory Setting and Pension Disclosures in France}

\section{The French Regulatory Setting}

France represents an interesting setting to study the effects of pension deficit disclosures on corporate financial policy for several reasons. First, defined benefit (DB) pension obligations of French listed companies are economically significant (pension-related debt is on average equal to $21 \%$ of the value of financial debt in the initial sample), which underscores the importance of examining the effect of pension deficits on company financial policies (Fried Frank, 2008). Second, the cost of higher effective leverage and creditor risk is exacerbated if employees and pension scheme members' claims are legally protected. In this respect, French bankruptcy law is extremely creditor unfriendly because it favors the survival of companies and the maintenance of employment over creditors' claims (Gaillot, 2008). ${ }^{1}$ Hence, we expect the relevance of pension deficits to creditors to be more pronounced in France than in other more creditor-friendly countries. Third, during our sample period there is no minimum funding requirement and no routine monitoring of DB pension plans by governmental bodies. Furthermore, in contrast to other countries such as the UK and the US there is no insurance of DB pension plans in France. ${ }^{2}$ Given that employees are higher in the pecking order than other creditors, we expect that creditor risk due to the incidence of unfunded pension plan deficits to be more significant in France than in countries where stricter funding requirements and insurance programmes are in place. ${ }^{3}$

\footnotetext{
${ }^{1}$ See the French Commercial Code 2010 (Book VI - Businesses in difficulty, as amended by Act No 2005-845 effective from 1 January 2006). Consistent with the view that bankruptcy law in France is creditor unfriendly, Davydenko and Franks (2008) find that default recovery rates are significantly lower in France than in both the UK and Germany, despite banks asking for more and different kinds of collateral in France.

${ }^{2}$ The Pension Protection Fund in the UK and the Pension Benefit Guarantee Corporation in the US provide insurance to pension fund members when plan sponsors become insolvent.

${ }^{3}$ For example, in the US the Pension Protection Act of 1987 stipulated that between $13.75 \%$ and $30 \%$ of any underfunding had to be deposited into the pension plan as either a deficit reduction contribution or catch up contribution (Rauh, 2006). Similarly, in the UK the Pension Act (1995) introduced the Minimum Funding Requirement from April 1997 and this was subsequently replaced by the Pensions Act from December 2005, which introduced stricter scheme-specific funding requirements.
} 
Importantly, the French setting presents a good setting to study the effects of pension transparency because domestic accounting standards required relatively limited disclosures of pension information before the adoption of IAS 19, which contrasts to other IFRS adopting countries such as the UK. ${ }^{4}$ The French Commercial Code (2006, Article L. 123-13) required information about pension and post-employment obligations to be reported in the notes to the financial statements. Companies also had the option to recognize the total or part of their pension deficit on the balance sheet. However, no specific valuation method was required in either case. Furthermore, financial reporting enforcement in France prior to IFRS adoption was weak (Depoers, 2000). As a consequence, many companies failed to recognize or disclose pension-related liabilities and deficits and there was a high degree of inconsistency when accounting for pensions in France. In an attempt to improve pensions-related financial reporting, the French National Accounting Authority, Conseil National de la Comptabilité, published a recommendation in April 2003 encouraging companies to value their pension deficit in accordance with IAS 19 and to recognize this in the balance sheet, despite early adoption of other IFRS standards not being allowed. Some companies voluntarily adopted the suggested approach espoused by IAS 19, but many other companies continued to provide little or no pensions-related information in their financial statements.

Indeed, the sample includes companies that neither recognized nor disclosed any pension deficit in 2004, but subsequently revealed a pension deficit under IAS 19 in their transition balance sheet when required to adopt IFRS in 2005. Other companies in our sample recognized or disclosed pension-related information without providing details as to how pension obligations were estimated. However, first-time IFRS adoption reconciliations suggest that

\footnotetext{
${ }^{4}$ For example, prior to IFRS adoption UK companies were required to recognize a net pension asset/liability under FRS 17.
} 
IAS 19, requiring the recognition of pension deficits at fair value, was not being applied in many cases.

In order to better understand the types of disclosures provided by early and mandatory adopters we have extracted, with the help of a linguistic engineer, all pension-related information from the annual reports of the companies in our sample. ${ }^{5}$ To facilitate this task, we developed a list of keywords to capture pension-related information. ${ }^{6}$ A French-speaking research assistant subsequently reviewed the extracts, collected and recorded information about the following categories of pension-related disclosures: (a) accounting standard adopted by the company, if any, (b) if companies recognize and/or disclose information about pension deficits or if they provide no information, (c) if they disclose information about pension obligations, (d) if they disclose information about pension assets, (e) if they provide information about pension expenses, (f) if they provide information about the discount rate, (g) if they provide information about other actuarial assumptions, and (h) if they provide information about pension contributions.

Based on the above process, Table OA.A1 in this Appendix presents information about the disclosures provided by both early and mandatory adopters. Panel A provides an overview of the extent of the disclosures made by companies for example the number of pages on which DB pension plans are discussed and the number of keywords identified. Panel B presents information about the pension deficit disclosures of early and mandatory adopters and Panel C summarizes the additional information provided by early and mandatory adopters.

Overall and consistent with the assumptions underlying the development of the hypotheses, mandatory adopters provide less information in 2004 compared to early adopters,

\footnotetext{
${ }^{5}$ We thank the anonymous reviewer for this suggestion.

${ }^{6}$ We used the following keywords when extracting pension-related information from the annual reports: avantage\#, annexe\# aux comptes, annexe\# des comptes, ias 19, actuariel\#, actuarielle\#, retraite\#, prestations définies, cotisations définies, fin de carrier, annexe\# aux états financiers, pension\#, employee benefit\#, retirement, pension\#, actuarial, r\#01.
} 
as indicated by the extent of the disclosures provided, i.e., number of pages and percentage of pages of relevant disclosures as well as the number of keywords, as indicated in OA.A1 Panel A. While by construction $100 \%$ of early adopters provide information about their pension deficits on the balance sheet in accordance with IAS 19, approximately $30 \%$ of the mandatory adopters either do not disclose information about their pension deficits or disclose such information off-balance sheet in the notes to the financial statements in 2004 , as indicated in Panel B. In addition, mandatory adopters were providing less information about the gross amount of pension obligations and pension assets compared to early adopters. The amount of information provided by mandatory adopters only increased after the adoption of IAS 19 in 2005.

Even though mandatory adopters do not provide as much information about pension deficits as early adopters, approximately $70 \%$ of mandatory adopters were recognizing at least part of their estimated pension deficit on the balance sheet. It is possible that the market used this information while trying to form expectations about these companies' pension deficits at the point of shifting to IFRS. However, it is important to note, that even in those cases the recognized pension deficit amount was not calculated in accordance with the provisions of IAS 19 (see Carrefour example below). Hence, even though these companies provided information about their pension deficits, which would have no doubt been somewhat useful to the market, it is not straightforward to infer how these deficits were estimated and the extent of their usefulness (see also results in Table OA.B6 below).

Overall, the above discussion supports the assumptions underlying the development of the hypotheses. Before 2005, reporting was very heterogeneous across companies in the context of recognizing or disclosing pension deficits in France, with early adopters of IAS 19 providing considerably more information. Even when mandatory adopters provided some information prior to the effective date of IAS 19, it is not clear how deficits were estimated thereby 
rendering the task of evaluating the information available even more difficult. The fact that early adopters complied with the requirements of IAS 19 early (i.e., before IAS 19 was mandated) allows us to develop an 'expected' pension deficit for non-early adopters (i.e., mandatory adopters who only adopted IAS 19 when it was compulsory in 2005).

Next, we present selected extracts from the annual reports of three companies to provide examples of the pension-related information available in company reports and accounts. One of those companies is Carrefour, a large international retail company. The notes to the 2004 financial statements prepared under local GAAP show Carrefour's pension obligation was valued at $€ 342.2$ million and the company reported a net pension plan deficit of $€ 179.10$ million; however, little information is provided about the valuation assumptions used. In its transition balance sheet, Carrefour recognized a net pension deficit of $€ 310$ million upon adoption of IFRS, almost double the amount recognized under local GAAP. At the other end of the spectrum is L'Oréal, a company which adopted IAS 19 as early as 2001. Pension-related extracts from L'Oréal's 2004 annual report are also presented below. 
Table OA.A1: Corporate Pension Disclosures of Early vs Mandatory Adopters.

\begin{tabular}{|c|c|c|c|c|c|c|}
\hline \multirow{5}{*}{$\begin{array}{l}\text { Type of disclosures } \\
\text { Panel } . \text { Frtont of } d i\end{array}$} & \multirow{3}{*}{\multicolumn{2}{|c|}{$\begin{array}{c}\frac{\text { Early }}{2004} \\
\text { Number } \\
\text { of obs. }\end{array}$}} & \multicolumn{4}{|c|}{ Mandatory } \\
\hline & & & \multicolumn{2}{|c|}{$\underline{2004}$} & \multicolumn{2}{|c|}{$\underline{2005}$} \\
\hline & & & \multirow[t]{2}{*}{$\begin{array}{c}\text { Number } \\
\text { of obs. }\end{array}$} & \multirow[t]{2}{*}{$\%$} & \multirow[t]{2}{*}{$\begin{array}{c}\text { Number } \\
\text { of obs. }\end{array}$} & \multirow[t]{2}{*}{$\%$} \\
\hline & & & & & & \\
\hline & \multicolumn{6}{|c|}{ Panel A: Extent of disclosures } \\
\hline Pages (n) & 164 & 11.66 & 162 & 8.51 & 171 & 14.43 \\
\hline Pages (\%) & 164 & 0.09 & 162 & 0.08 & 171 & 0.12 \\
\hline Keywords & 164 & 33.51 & 162 & 23.48 & 171 & 44.92 \\
\hline \multicolumn{7}{|c|}{ Panel B: Deficit amount } \\
\hline On-Balance Sheet & 177 & $100 \%$ & 171 & $59.06 \%$ & 171 & $100 \%$ \\
\hline Off-balance sheet & 177 & $0.00 \%$ & 171 & $16.37 \%$ & 171 & $0.00 \%$ \\
\hline Combination & 177 & $0.00 \%$ & 171 & $10.53 \%$ & 171 & $0.00 \%$ \\
\hline Neither & 177 & $0.00 \%$ & 171 & $14.04 \%$ & 171 & $0.00 \%$ \\
\hline \multicolumn{7}{|c|}{ Panel C: Other information } \\
\hline Plan Obligation & 164 & $22.56 \%$ & 162 & $16.05 \%$ & 171 & $26.90 \%$ \\
\hline Plan Assets & 164 & $20.73 \%$ & 162 & $10.49 \%$ & 171 & $26.32 \%$ \\
\hline Pension Expense & 164 & $25.61 \%$ & 162 & $8.64 \%$ & 171 & $36.26 \%$ \\
\hline Asset Allocation & 164 & $5.49 \%$ & 162 & $1.85 \%$ & 171 & $7.60 \%$ \\
\hline Discount Rate & 164 & $78.05 \%$ & 162 & $46.95 \%$ & 171 & $80.70 \%$ \\
\hline Other Assumptions & 164 & $79.88 \%$ & 162 & $51.85 \%$ & 171 & $83.04 \%$ \\
\hline Contributions & 164 & $6.10 \%$ & 162 & $1.85 \%$ & 171 & $9.94 \%$ \\
\hline
\end{tabular}

Notes: Table OA.A1 presents information about the pension disclosures of early and mandatory adopters. In Panel A, we present information about the extent of pension disclosures in the annual reports of early and mandatory adopters. Pages $(n)$ is the number of pages over which DB pension schemes are discussed. Pages $(\%)$ is the number of pages over which DB pension schemes are discussed scaled by the total number of pages in the annual report. Keywords is the number of times pension-related keywords (avantage\#, annexe\# aux comptes, annexe\# des comptes, IAS 19, actuariel\#, actuarielle\#, retraite\#, prestations définies, cotisations définies, fin de carrier, annexe\# aux états financiers; pension\#, employee benefit\#, retirement, pension\#, actuarial, r\#01) appear in the annual report. In Panel B, we present the \% of early and mandatory adopters providing information about pension deficits by distinguishing between pension deficit information (a) recognized on the balance sheet, (b) disclosed off-balance sheet, (c) both (a) and (b), and (d) neither (a) nor (b). Panel C presents information about additional disclosures provided in the notes to the financial statements by early and mandatory adopters. 


\section{Example 1: Carrefour}

Carrefour is a multinational retailer. In 2005 Carrefour was the largest retailer in Europe and the $2^{\text {nd }}$ largest internationally. Carrefour adopted IAS 19 mandatorily in 2005. On Dec. $31^{\text {st }}$ 2005 Carrefour had total assets of 46.25 billion euros and its market capitalization was 27.90 billion euros.

\section{Annual Report}

Managers name IAS 19 as one of the two IFRS standards with the highest expected impact, without however providing an estimation of this impact:

'The standards which would have a significant impact on the opening stockholders' equity are the following:

- IAS Standard 19 regarding employee benefits;

- IAS Standard 2 regarding stock-based payments.'

In Note 1: Accounting principles it is further mentioned that:

'Pursuant to Regulation 2000-06 of the Accountancy Regulatory Committee regarding liabilities, any Group obligation with respect to a third party likely to be estimated with sufficient reliability as likely to give rise to resources without counterparty is subject to the establishment of a provision. Carrefour pays retirement benefits to all persons who work for the Group up until retirement in France and in other countries. All employee benefits are accounted for. This commitment is calculated on an actuarial basis, taking into account factors such as personnel rotation, mortality and salary increases. Commitments are met through contributions paid to outside agencies or in the form of provisions.'

Note 23: Provisions for contingencies and long-term liabilities:

Note 23: Provisions for contingencies and long-term liabilities

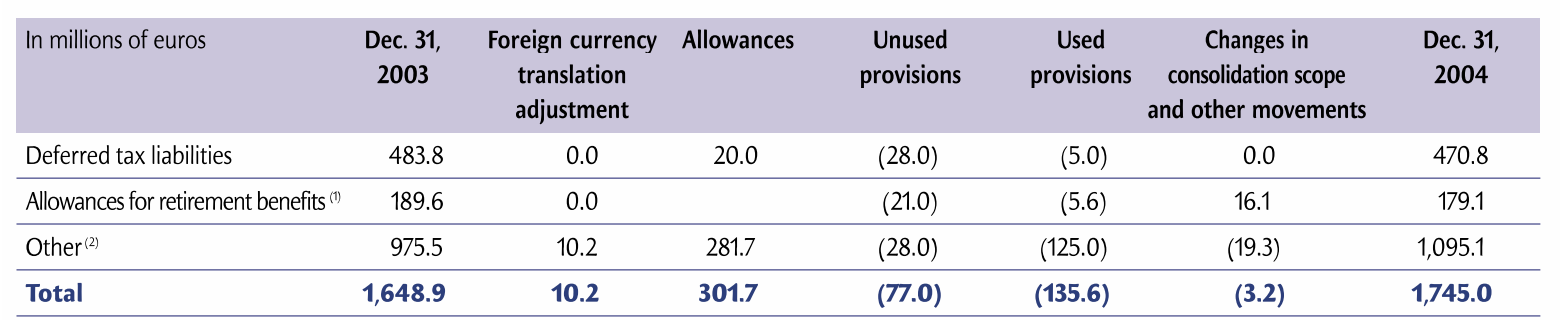

(1) The allowance for retirement benefits is determined at the end of each year by taking into account employee seniority and the probability of their presence in the company at retirement. The calculation is based on an actuarial method integrating hypotheses for changes in salaries and the retirement age. The Group's total allowance as of December 31, 2004 was estimated at 342.2 million euros. It is fully covered by provisions and by payments to outside agencies.

(2) These provisions consist of items related to fiscal and legal risks, with the rest covering risks directly associated with the operations of the company (after sales service disputes, labour risks, etc.).

No other information is provided with regards to the pension deficit calculations (Carrefour, 2004). 


\section{Annual Report}

Note 1: Accounting principles includes the following extracts relating to pension plans:

'The main estimates made by management when preparing the financial statements concern the valuations and useful lives of current and non-current operating assets and goodwill, the amount of provisions for risks and other provisions relating to the business, as well as assumptions made for the calculation of retirement pension commitments or deferred taxes. Details of the main assumptions retained by the Group are provided in each of the paragraphs in the Appendix devoted to the financial statements.

\section{$[\ldots]$}

Employee benefits

The Group's employees enjoy short-term benefits (paid leave, sick leave, profit-sharing), longterm benefits (long-service medals, seniority bonus etc.) and post-employment advantages on the basis of specific contributions/benefits (retirement benefit).

\section{$[\ldots]$}

\section{$b$ - Schemes with defined benefits and long-term advantages}

The Carrefour Group makes provision for the various defined benefit schemes dependent on the accumulated years of service within the Group that are not totally pre-financed.

This commitment is calculated annually on the basis of the method of projected units of credit, on an actuarial basis, taking into consideration factors such as salary increases, age of departure, mortality, personnel rotation and discount rates.

The Group has decided to apply the "corridor" method, whereby the effect of variations in actuarial terms is not recognized on the income statement, as long as the former remain within a range of $10 \%$. Thus actuarial differences exceeding $10 \%$ between the value of the commitment and the value of the hedging assets - whichever is the higher-are spread on the income statement over the expected average working life of employees benefiting from this scheme.

In accordance with the option offered by IFRS 1, the Group has chosen to record all its actuarial losses and gains in its pension commitments that have not yet been recognized in the French financial statements at December 31, 2003, directly, corresponding to shareholders' equity at January 1, 2004.' 
The pension-related expense and liability are discussed in Note 10 and Note 24 respectively:

\section{Note 10}

\section{INTEREST INCOME}

\begin{tabular}{|c|c|c|c|}
\hline (in millions of euros) & $31 / 12 / 2005$ & $\begin{array}{l}31 / 12 / 04 \text { published } \\
\text { restated Dep / } 40 \text { yrs }\end{array}$ & $\begin{array}{l}31 / 12 / 2004 \\
\text { IFRS }\end{array}$ \\
\hline Other financial expenses and income & $(58.7)$ & $(82.6)$ & $(82.6)$ \\
\hline Net debt expense & (395.9) & (401.9) & (395.6) \\
\hline Income from cash and cash equivalents & 34.3 & 37.6 & 37.6 \\
\hline Interest expenses & $(398.4)$ & $(404.8)$ & $(398.5)$ \\
\hline Interest expenses for financial leasing operations & $(31.8)$ & $(34.7)$ & $(34.7)$ \\
\hline TOTAL & (454.6) & $(484.5)$ & $(478.2)$ \\
\hline
\end{tabular}

Other interest income and expenses include the cost of discounting provisions for retirement pensions, 33.3 million euros at December 31 , 2005 and 34.7 million euros at December 31, 2004.

The breakdown of the Group's debt is shown in Note 26 on borrowings.

\section{Note 24}

\section{PROVISIONS}

\begin{tabular}{lcccccc|c|} 
& $\begin{array}{c}31 / 12 / 2004 \\
\text { IFRS }\end{array}$ & $\begin{array}{c}\text { Currency } \\
\text { impact }\end{array}$ & $\begin{array}{c}\text { Allow- } \\
\text { ances }\end{array}$ & $\begin{array}{c}\text { Capitaliza- } \\
\text { tion }\end{array}$ & $\begin{array}{c}\text { Unused } \\
\text { reversals of } \\
\text { provisions }\end{array}$ & $\begin{array}{c}\text { Used } \\
\text { reversals of } \\
\text { provisions }\end{array}$ & $31 / 12 / 2005$ \\
\hline $\begin{array}{l}\text { Provilions of euros) } \\
\text { Other provisions }\end{array}$ & 732 & 3 & 68 & 31 & $(40)$ & $(61)$ & 734 \\
\hline TOTAL & 1,222 & 109 & 659 & & $(134)$ & $(266)$ & 1,597 \\
\hline
\end{tabular}

The cost of retirement indemnities is determined at the end of each fiscal year on the basis of employee seniority and the probability of their presence in the company at retirement. The calculation is based on an actuarial method that incorporates assumptions as to salary increases and the age of retirement. The commitment of the Group is entirely covered by provisions and by payments to external agencies,

Half the other provisions consist of items relating to tax and legal risks, with the rest covering risks directly relating to the company's operations (after-sales service disputes, labour risks etc.)

Group companies are involved in a certain number of legal proceedings and disputes in the normal course of business, including disputes with the social security and tax authorities. Expenses liable to be estimated with a sufficient level of reliability and deemed to be probable by the companies and their experts are subject to the establishment of a provision for contingencies and loss. 
The reports also include a table reconciling the 2004 French GAAP and IFRS balance sheets:

Main adjustments to the balance sheet at December 31, 2004, drawn up in accordance with French standards, with the balance sheet at December 31, 2004 drawn up in accordance with IFRS

ASSETS

\begin{tabular}{|c|c|c|c|c|c|c|}
\hline (in millions of euros) & $\begin{array}{l}\text { Consolidation of } \\
\text { finance companies } \\
\text { (IAS 27) }\end{array}$ & $\begin{array}{l}\text { Ending of } \\
\text { goodwill } \\
\text { amortization }\end{array}$ & $\begin{array}{c}\text { Employee } \\
\text { benefits } \\
\text { (IAS 19) }\end{array}$ & $\begin{array}{c}\text { Financial } \\
\text { leasing } \\
\text { (IAS 17) }\end{array}$ & $\begin{array}{l}\text { Inven- } \\
\text { tories } \\
\text { (IAS 2) }\end{array}$ & $\begin{array}{l}\text { Pre-opening } \\
\text { costs and } \\
\text { rebates }\end{array}$ \\
\hline
\end{tabular}

\section{Goodwill}

319

Other intangible fixed assets

Tangible fixed assets

Financial assets

$3 \quad 226$

Investments in companies accounted

for by the equity method

Deferred tax assets

Investment properties

Consumer credit from financial

\begin{tabular}{llll} 
companies & 1,594 & & \\
\hline Non-current assets & 1,312 & 319 & 207
\end{tabular}

Inventories

Commercial receivables

Consumer credit from financial

companies - short term $\quad 1,617$

Other assets 57

Cash and cash equivalents $\quad 306$

$\begin{array}{llll}\text { Current assets } & 1,980 & & \text { (635) } \\ \text { Total assets } & \mathbf{3 , 2 9 2} & \mathbf{3 1 9} & \mathbf{2 0 7}\end{array}$

LIABILITIES

\begin{tabular}{|c|c|c|c|c|c|c|}
\hline (in millions of euros) & $\begin{array}{c}\text { Consolidation of } \\
\text { finance companies } \\
\text { (IAS 27) }\end{array}$ & $\begin{array}{l}\text { Closing of } \\
\text { goodwill } \\
\text { amortization }\end{array}$ & $\begin{array}{l}\text { Employee } \\
\text { benefits } \\
\text { (IAS 19) }\end{array}$ & $\begin{array}{l}\text { Financial } \\
\text { leasing } \\
\text { (IAS 17) }\end{array}$ & $\begin{array}{l}\text { Inven- } \\
\text { tories } \\
\text { (IAS 2) }\end{array}$ & $\begin{array}{c}\text { Pre-opening } \\
\text { costs and } \\
\text { rebates }\end{array}$ \\
\hline Shareholders' equity, Group share & 2 & 319 & $(318)$ & (37) & $(418)$ & $(22)$ \\
\hline Shareholders' equity, non-Group share & 209 & & (2) & (6) & $(36)$ & $(4)$ \\
\hline Shareholders' equity & 211 & 319 & $(320)$ & (43) & $(454)$ & (26) \\
\hline
\end{tabular}

\section{Borrowings}

Provisions

$81-531$

Deferred tax liabilities

Bank loan refinancing 255

Non-current liabilities 547

Borrowings - less than 1 year

Trade payables

Consumer credit from financial

companies - short term 2,654

Tax payables

Other liabilities

Current liabilities

2,745

0

(211)

319

0

250

3,292

207

(635)

(26)

No other information is provided with regards to the pension deficit calculations (Carrefour, 2005). 


\section{Example 2: ORPEA}

ORPEA is a leading European operator in dependency care. ORPEA adopted IAS 19 mandatorily in 2005. On Dec. $31^{\text {st }} 2005$ ORPEA had total assets of 853.96 million euros and its market capitalization was 832.81 million euros.

\section{Annual Report}

The only discussion about the company's pension plans can be found in Note 17:

'Note 17: Off balance-sheet commitments

The amount of pension commitments, determined using an actuarial method, totalled $€ 1,008,000$ at December 312004.

For information purposes, the amount paid by the Group in retirement payments totalled $€ 88,000$ in 2004.' (Orpea, 2004).

\section{Annual Report (translated)}

In the accounting principles sections of the notes it is stated that:

\section{'1.19. Pension and other employee benefits}

The amounts of the group's commitments in terms of pensions, retirement supplements and severance pay are subject to provisions estimated on the basis of actuarial valuations. These commitments are calculated using a retrospective method with projected salaries. The main actuarial assumptions used are presented in paragraph 3.11 .

The cumulative effects of actuarial gains and losses resulting from experience adjustments or changes in assumptions related to financial, general economic or demographic conditions (change in discount rate, annual salary increases, duration of activity, etc.) are recognized immediately in the amount of the Group's commitment, against a separate heading of equity, "Other reserves", based on the option allowed by amended IAS 19.'

Further Note 3.11. Provision for retirement and similar commitments reads:

'The group provides its employees only with retirement benefits. No other post-employment benefits are granted or any long-term benefit to the active staff.

The Orpea group applies the single collective agreement FHP of April 18, 2002, which grants an allowance at the time of retirement, the amount of which depends on the seniority of the employee, his classification and the end-of-career salary.

These pension commitments are not covered by outsourced funds.

Commitments to staff are calculated using a retrospective method with projected end-of-career salaries. The main actuarial assumptions used as of December 31, 2004 and December 31, 2005 are as follows:

- discount rate: $4.5 \%$;

- annual salary revaluation rate: $4 \%$ taking into account inflation; 
- retirement age: 65 years old;

- social contribution rate: $48.6 \%$ for retirement homes and $58.7 \%$ for clinics;

In accordance with the amendment to IAS 19 of December 16, 2004 applied in advance, the cumulative amount of actuarial gains and losses is recognized in equity.'

The company also provided information about the evolution of the pension liability over the year as well as a reconciliation table between French GAAP and IFRS which includes the transition impact on the recognized pension liability:

L'évolution de la situation financière des engagements de retraite et assimilés se détaille comme suit :

\begin{tabular}{|c|c|c|c|c|c|c|c|c|}
\hline & Valeur actuelle & Juste valeur & Position nette & & sion au bilar & & & Capitaux \\
\hline & l'obligation & & & passifs & actifs & net & de l'exercice & propres \\
\hline Ouverture & 2162 & & -2162 & -2162 & & -2162 & 0 & \\
\hline Coût des services courants & 356 & & -356 & -356 & & -356 & -356 & \\
\hline $\begin{array}{l}\text { Charge d'intérêt } \\
\text { (désactualisation) }\end{array}$ & 85 & & -85 & -85 & & -85 & -85 & \\
\hline Rendements attendus des actifs & & & & & & & & \\
\hline Cotisations des salariés & & & & & & & & \\
\hline Cotisations de l'emplo yeur & & 218 & 218 & 218 & & 218 & & \\
\hline Gains et pertes actuariels & -81 & & 81 & 81 & & 81 & & 81 \\
\hline Plafonnement de l'actif & & & & & & & & \\
\hline Ecarts de conversion (devises) & & & & & & & & \\
\hline Prestations de retraite payées & -218 & -218 & & & & & & \\
\hline Coût des services passés & & & & & & & & \\
\hline Variations de périmètre & 889 & & -889 & -889 & & -889 & & \\
\hline Réductions de plans & & & & & & & & \\
\hline Liquidations de plans & & & & & & & & \\
\hline Clôture & 3193 & 0 & -3193 & -3193 & 0 & -3193 & -441 & 81 \\
\hline
\end{tabular}


Bilan consolidé :

\begin{tabular}{|c|c|c|c|c|c|c|}
\hline En milliers d'euros & Notes & $\begin{array}{l}31 / 12 / 2004 \\
\text { Normes } \\
\text { françaises }\end{array}$ & $\begin{array}{c}\text { Rééva- } \\
\text { luation des } \\
\text { autori- } \\
\text { sations }\end{array}$ & $\begin{array}{c}\text { Capita- } \\
\text { lisation des } \\
\text { contrats de } \\
\text { location- } \\
\text { finan- } \\
\text { cement }\end{array}$ & Autres & $\begin{array}{l}\text { 31/12/2004 } \\
\text { IFRS }\end{array}$ \\
\hline \multicolumn{7}{|l|}{ Actif } \\
\hline Goodwill & 4.4 .4 & 13501 & \multirow{3}{*}{132679} & \multirow[b]{3}{*}{108819} & -7643 & 5858 \\
\hline Immobilisations incorporelles nettes & 4.4 .1 & 114812 & & & \multirow[t]{2}{*}{2330} & 249821 \\
\hline Immobilisations corporelles nettes & 4.4.2-3 & 133334 & & & & 242153 \\
\hline Stocks immobiliers & & 60158 & & & \multirow{4}{*}{6233} & 60158 \\
\hline Titres mis en équivalence & & 70509 & & & & 76742 \\
\hline Actifs financiers non courants & & 4908 & & & & 4908 \\
\hline Actifs d'impôt différé & & 1792 & & & & 1792 \\
\hline Actif non courant & & 399014 & \multirow[t]{7}{*}{132679} & \multirow[t]{7}{*}{108819} & 920 & 641432 \\
\hline Stocks et en-cours & & 85 & & & 612 & 697 \\
\hline Créances clients & & 19458 & & & 4385 & 23843 \\
\hline Autres créances & & 20784 & & & -4524 & 16260 \\
\hline Actifs d'impôt exigible & & & & & & - \\
\hline Comptes de régularisation et assimilés & & 1966 & & & -1330 & 636 \\
\hline Trésorerie et équivalents de trésorerie & & 11380 & & & -4516 & 6864 \\
\hline Actif courant & & 53673 & - & - & -5373 & 48300 \\
\hline Total de l'actif & & 452687 & 132679 & 108819 & -4453 & 689732 \\
\hline \multicolumn{7}{|l|}{ Passif } \\
\hline Capital & \multirow{19}{*}{4.4 .5} & 44827 & \multirow{4}{*}{73919} & \multirow{4}{*}{7851} & & 44827 \\
\hline Réserves de réévaluation & & & & & 23449 & 105219 \\
\hline Réserves consolidées & & 74251 & & & -26431 & 47820 \\
\hline Subvention d'investissement & & 1700 & & & -1700 & - \\
\hline Capitaux propres - part du groupe & & 120778 & 73919 & 7851 & -4682 & 197866 \\
\hline Intérêts minoritaires & & 1547 & & & & 1547 \\
\hline $\begin{array}{l}\text { Capitaux propres de l'ensemble } \\
\text { consolidé }\end{array}$ & & 122325 & 73919 & 7851 & -4682 & 199413 \\
\hline $\begin{array}{l}\text { Provisions pour risques et charges - part à } \\
\text { long terme }\end{array}$ & & 5941 & & \multirow{4}{*}{$\begin{array}{r}60949 \\
0617\end{array}$} & 2386 & 8327 \\
\hline Provisions pour engagements de retraite & & & & & \multirow[t]{2}{*}{2162} & 2162 \\
\hline Dettes financières à long terme & & 188811 & & & & 249760 \\
\hline Passifs d'impôt différé & & 16917 & 58760 & & -4319 & 80975 \\
\hline Passif non courant & & 211669 & \multirow{6}{*}{58760} & \multirow{6}{*}{$\begin{array}{l}70566 \\
30402\end{array}$} & \multirow[t]{6}{*}{229} & 341224 \\
\hline Dettes financières à court terme & & 23150 & & & & 53552 \\
\hline Fournisseurs & & 24725 & & & & 24725 \\
\hline Dettes fiscales et sociales & & 33981 & & & & 33981 \\
\hline Passif d'impôt exigible & & & & & & - \\
\hline Autres dettes & & 36837 & & & & 36837 \\
\hline Passif courant & & 118693 & - & 30402 & - & 149095 \\
\hline Total du passif & & 452687 & 132679 & 108819 & -4453 & 689732 \\
\hline
\end{tabular}

(Orpea, 2005). 


\section{Example 3: L’Oréal}

L'Oréal is a leading personal care company. L'Oréal adopted IAS 19 voluntarily in 2001. On Dec. $31^{\text {st }} 2005$ L'Oréal had total assets of 23.89 billion euros and its market capitalization was 41.37 billion euros.

\section{$\underline{2004 \text { Annual Report }}$}

In Note 1: Accounting principles reads as follows:

'The group has decided to recognize in its consolidated financial statements all the liabilities generated by employee retirement obligation and related benefits from January $1^{\text {st }} 2001$.

The group adheres to pensions, early retirement and other benefit schemes depending on local legislation and regulations.

The characteristics of the existing schemes are as follows: - French regulations provide for specific length-of-service awards payable to employees on retirement. In addition, an early retirement plan and a defined benefit plan have been set up. In some group companies there are also measures providing for the payment of certain healthcare costs for retired employees.

These obligations, except for those relating to healthcare costs for retired employees, are partially funded.

- For foreign subsidiaries with employee pension schemes or other specific obligations relating to defined benefits, the excess of obligations over the scheme's assets is recognized by setting up a provision for charges on the basis of the actuarial value of the vested rights of employees.

The charges recorded in the profit and loss account, under the heading Personnel costs, include:

- service cost, i.e. additional rights acquired by employees during the accounting period,

- interest cost, i.e. change in the value of the discounted rights due to the fact that one year has passed,

- expected return on assets, i.e. income from external assets calculated on the basis of a standard return on long-term investments,

- the impact of any change to existing schemes on previous years or of any new schemes,

- amortization of unrecognized gains and losses, i.e., depreciation of any variation from the actuarial calculation.

To determine the discounted value of the obligation for each scheme, the group applies an actuarial valuation method based on the final salary (projected credit unit method). The obligations and the fair value of assets are assessed each year, using length-of-service, life expectancy, staff turnover by category and economic assumptions (inflation rate and discount rate).

The cumulative effects of unrecognized gains and losses are depreciated over the average residual period of activity of active employees, unless such gains and losses do not exceed 10\% 
of the greater of the discounted benefit obligation or the fair value of plan asset (corridor principle). The depreciation is included in the annual actuarial charge of the following financial year. Gains and losses in relation to other benefits, such as jubilees and medals, are immediately charged to the profit and loss account without the application of the corridor principle.

The debt relating to the company's net obligation is recorded as a liability on the balance sheet, under the heading Provisions for liabilities and charges.

Further Note 15: Provision for liabilities and charges provides the following information:

\section{NOTE 15 - PROVISIONS FOR LIABILITIES AND CHARGES}

a - Balances at closing date

\begin{tabular}{lrr}
\hline$€$ millions & 12.31 .2004 & \\
\hline Provisions for employee retirement obligation and related benefits & 787.1 & 12.31 .2003 \\
\hline Deferred tax liabilities & 659.9 & 906.3 \\
\hline Other provisions for liabilities and charges & $(1)$ & 427.7 \\
\hline Provisions for restructuring & 46.9 & 40.5 \\
\hline Total & $\mathbf{1 , 9 2 1 . 6}$ & 461.5 \\
\hline
\end{tabular}

(1) This item includes provisions facing tax risks and litigation, industrial and commercial risks relating to operations (breach of contract, product returns) and personnel costs.

c - Provisions for employee retirement obligation and related benefits

Employee retirement obligation and related benefits include in particular:

- pensions and benefits linked to retirement and/or early retirement,

- social benefits for retired employees (pensions, retirement bonuses, life insurance, medical assistance, etc.),

- other long-term benefits (gifts and long service awards).

Provisions for pensions and early retirement

Employee retirement obligations are calculated using an actuarial valuation method based on the projected final salary (projected credit unit method). With regard to retirement obligations, the calculation is made so as to charge each period of service rendered by a group employee with a straight-line unit of its final obligation. Since January $1^{\text {st }} 2001$, provisions have been booked for all obligations relating to pensions still to be paid to retired employees and the vested rights of employees.

Other long-term and post employment benefits

These benefits have been evaluated on the basis of the same actuarial assumptions as those used to calculate pensions. Provisions have been made for all obligations relating to retired employees and for the vested rights of employees.

The actuarial assumptions used to calculate these obligations take into account the economic conditions in each country or in each group company. The average weighted assumptions for the group are as follows:

\begin{tabular}{lrr}
\hline & 12.31 .2004 & 12.31 .2003 \\
\hline - Discount rate & $5.1 \%$ & $5.5 \%$ \\
- Salary increase & $4.6 \%$ & $4.5 \%$ \\
- Long-term return on assets & $6.2 \%$ & $6.4 \%$ \\
\hline
\end{tabular}


The variations during 2004 and 2003 are set out below:

\begin{tabular}{|c|c|c|c|c|}
\hline$€$ millions & $\begin{array}{r}\text { Projected } \\
\text { pension } \\
\text { obligation }\end{array}$ & Assets & $\begin{array}{r}\text { Unrealised } \\
\text { gains and } \\
\text { losses }\end{array}$ & $\begin{array}{r}\text { Net } \\
\text { provision }\end{array}$ \\
\hline Balance at December $31^{\text {st }} 2002$ & $1,781.5$ & 679.4 & 205.8 & 896.3 \\
\hline \multicolumn{5}{|l|}{ Net charge for the year: } \\
\hline - Service cost & 89.8 & & & 89.8 \\
\hline - Interest cost & 95.9 & & & 95.9 \\
\hline - Expected return on assets & & 43.6 & & -43.6 \\
\hline - Amortisation of unrealised gains and losses & & & -10.3 & 10.3 \\
\hline Benefits paid & -65.3 & -38.5 & & -26.8 \\
\hline Contributions paid & 5.4 & 115.8 & & -110.4 \\
\hline Unrealised gains and losses & 57.4 & 38.9 & 18.5 & 0.0 \\
\hline Translation differences & -87.5 & -56.8 & -25.3 & -5.4 \\
\hline Other movements & 0.2 & & & 0.2 \\
\hline Balance at December $31^{\text {st }} 2003$ & $1,877.4$ & 782.4 & 188.7 & 906.3 \\
\hline \multicolumn{5}{|l|}{ Net charge for the year: } \\
\hline - Service cost & 91.3 & & & 91.3 \\
\hline - Interest cost & 94.8 & & & 94.8 \\
\hline - Expected return on assets & & 54.5 & & -54.5 \\
\hline - Amortisation of unrealised gains and losses & & & -7.5 & 7.5 \\
\hline - Reserval of provisions ${ }^{(1)}$ & -34.4 & & 1.2 & -35.6 \\
\hline Benefits paid & -81.5 & -48.0 & & -33.5 \\
\hline Contributions paid & 5.6 & 138.5 & & -132.9 \\
\hline Unrealised gains and losses & 187.2 & 24.3 & 162.9 & - \\
\hline Translation differences & -34.2 & -24.1 & -9.1 & -1.0 \\
\hline Other movements & -52.6 & 3.0 & -0.3 & -55.3 \\
\hline Balance at December $31^{\text {st }} 2004$ & $2,053.6$ & 930.6 & 335.9 & 787.1 \\
\hline
\end{tabular}

The retirement expense charged to the profit and loss account may be analysed as follows:

\begin{tabular}{lrrr}
\hline$€$ millions & 12.31 .2004 & \\
\hline Service cost & 91.3 & 12.31 .2003 \\
\hline Interest cost & 94.8 & \\
\hline Expected return on assets & -54.5 & \\
\hline Amortisation of unrealised gains and losses & 7.5 & 95.9 \\
\hline Reversal of provisions ${ }^{(1)}$ & -35.6 & -43.6 \\
\hline Total & 103.5 & \\
\hline
\end{tabular}

(1) Other movements include $€ 57.2$ million in reversals of provisions previously booked against shareholders' equity at adoption of preferential method pursuant to CRC regulation $99-02$. The change in this commitment also resulted in a $€ 35.6$ million reduction in expenses for 2004 .

In other sections, information is provided about the CEO membership in the pension plan and the amount of deferred taxes associated with pension liabilities (L'Oréal, 2004).

\section{Annual Report}

The 2005 Annual Report provides similar pension information (L'Oréal, 2005). 
Appendix B - Additional Analysis

Table OA.B1: Descriptive Statistics for Mandatory Adopters in the Year of Adoption.

\begin{tabular}{|c|c|c|c|c|c|c|}
\hline & \multicolumn{2}{|c|}{ Excess Leverage } & \multicolumn{2}{|c|}{ Credit Rating } & \multicolumn{2}{|c|}{ Merton Default Probability } \\
\hline & $\begin{array}{c}\text { Low Risk } \\
\text { (1) }\end{array}$ & $\begin{array}{c}\text { High Risk } \\
\text { (2) }\end{array}$ & $\begin{array}{c}\text { Low Risk } \\
\text { (3) }\end{array}$ & $\begin{array}{c}\text { High Risk } \\
\text { (4) }\end{array}$ & $\begin{array}{c}\text { Low Risk } \\
\text { (5) }\end{array}$ & $\begin{array}{c}\text { High Risk } \\
\text { (6) }\end{array}$ \\
\hline Surprise & 0.009 & 0.002 & 0.006 & 0.007 & 0.006 & 0.006 \\
\hline Predicted & 0.014 & 0.016 & 0.017 & 0.011 & 0.015 & 0.014 \\
\hline$\Delta L e v$ & 0.005 & -0.036 & -0.009 & -0.021 & -0.006 & -0.025 \\
\hline Lev & 0.137 & 0.327 & 0.217 & 0.224 & 0.195 & 0.263 \\
\hline $\operatorname{Lev}_{t-1}$ & 0.118 & 0.371 & 0.224 & 0.236 & 0.191 & 0.291 \\
\hline$\Delta D C o s t$ & 0.000 & 0.004 & -0.006 & 0.020 & -0.002 & 0.008 \\
\hline DCost & 6.220 & 4.483 & 4.599 & 7.353 & 5.506 & 5.403 \\
\hline$D_{C o s t} t_{t-1}$ & 6.340 & 4.114 & 5.246 & 5.661 & 5.799 & 4.635 \\
\hline$\Delta D M a t$ & -0.012 & 0.009 & -0.010 & 0.012 & -0.013 & 0.014 \\
\hline DMat & 0.478 & 0.570 & 0.541 & 0.468 & 0.529 & 0.498 \\
\hline${ }^{D M a t} t_{t-1}$ & 0.486 & 0.561 & 0.549 & 0.453 & 0.538 & 0.485 \\
\hline CrRate & 9.505 & 8.689 & 10.248 & 6.778 & 10.083 & 7.516 \\
\hline CrRate $_{t-1}$ & 8.258 & 8.014 & 9.009 & 6.296 & 8.688 & 7.210 \\
\hline EqIssue & 0.011 & 0.027 & 0.015 & 0.024 & 0.017 & 0.019 \\
\hline EqIssue $_{\mathrm{t}-1}$ & 0.017 & 0.017 & 0.013 & 0.024 & 0.010 & 0.029 \\
\hline Div & 0.017 & 0.010 & 0.015 & 0.012 & 0.019 & 0.005 \\
\hline$D i v_{t-1}$ & 0.014 & 0.006 & 0.013 & 0.005 & 0.014 & 0.004 \\
\hline Size & 19.272 & 19.564 & 19.970 & 18.159 & 19.725 & 18.824 \\
\hline ASize & 0.123 & 0.072 & 0.122 & 0.055 & 0.136 & 0.039 \\
\hline Profit & 0.074 & 0.057 & 0.084 & 0.030 & 0.092 & 0.022 \\
\hline AProfit & 0.004 & 0.012 & 0.003 & 0.018 & 0.007 & 0.008 \\
\hline Risk & 0.037 & 0.036 & 0.025 & 0.061 & 0.028 & 0.051 \\
\hline$\Delta R i s k$ & -0.003 & -0.004 & -0.002 & -0.006 & -0.005 & 0.000 \\
\hline Growth & 0.081 & 0.068 & 0.085 & 0.055 & 0.087 & 0.055 \\
\hline AGrowth & 0.013 & 0.005 & 0.009 & 0.012 & 0.013 & 0.004 \\
\hline Tang & 0.164 & 0.198 & 0.192 & 0.149 & 0.169 & 0.194 \\
\hline ATang & -0.004 & -0.005 & -0.004 & -0.004 & -0.005 & -0.003 \\
\hline $\operatorname{Tax}$ & 0.020 & 0.017 & 0.024 & 0.008 & 0.025 & 0.008 \\
\hline$\Delta T a x$ & -0.003 & 0.000 & -0.001 & -0.004 & 0.000 & -0.006 \\
\hline AMat & 9.305 & 9.775 & 8.723 & 11.173 & 9.447 & 9.594 \\
\hline$\Delta A M a t$ & 0.496 & -1.476 & 0.317 & -1.698 & -0.065 & -0.779 \\
\hline$M / B$ & 1.984 & 1.649 & 1.825 & 1.868 & 1.969 & 1.610 \\
\hline
\end{tabular}




$\begin{array}{lcccccc}\text { ProfCash } & \mathbf{0 . 1 1 3} & \mathbf{0 . 0 6 3} & 0.090 & 0.095 & \mathbf{0 . 1 0 9} & \mathbf{0 . 0 6 1} \\ \boldsymbol{R} \& \boldsymbol{D} & 0.022 & 0.027 & \mathbf{0 . 0 1 9} & \mathbf{0 . 0 3 5} & 0.021 & 0.029 \\ \text { Float } & 41.000 & 41.716 & 42.333 & 39.093 & \mathbf{4 3 . 9 6 3} & \mathbf{3 6 . 6 4 5}\end{array}$

Notes: Table OA.B1 presents descriptive statistics for low and high financial risk mandatory adopters separately. Surprise is the difference between the restated IFRS pension deficit at the beginning of the adoption year and the fitted value from regression 1 (Predicted). Lev is the ratio of total financial debt over total assets. DCost is the average borrowing cost. DMat is the ratio of longterm financial over total financial debt. CrRate is the company's S\&P credit rating. EqIssue is the net proceeds from equity offerings scaled by total assets. Div is total dividend for the year deflated by total assets. Size is the natural logarithm of total assets. Profit is the return on operating assets (ROA) defined as operating income over total assets. Risk is the three-year standard deviation of ROA. Growth is next year's investing cash flows deflated by total assets and multiplied by minus one. Tang is defined as the ratio of fixed assets over total assets. Tax is taxes paid deflated by sales. AMat is defined as (gross PPE / total assets) $\times$ (gross PPE / depreciation expense $)+($ current assets / total assets $) \times$ (current assets / cost of goods sold). $M / B$ is the market value of equity at fiscal year-end divided by the book value of equity. ProfCash is defined as cash balance at the beginning of the year minus net proceeds of equity offering during the previous year scaled by total assets. $R \& D$ is the ratio of investment in research and development activities over total assets. Float is the stocks' free float ratio. Observations in bold indicated a statistically significant difference, at the $10 \%$ level or lower, between low and high financial risk companies. 
Table OA.B2: Correlation Matrix.

\begin{tabular}{|c|c|c|c|c|c|c|c|c|c|c|c|c|c|c|}
\hline & $\Delta L e v$ & $\triangle D C o s t$ & $\triangle D M a t$ & Surprise & Predicted & AProfit & ARisk & ATang & AGrowth & $\Delta T a x$ & $L e v_{t-1}$ & CrRate $_{t-1}$ & $\Delta A M a t$ & ASize \\
\hline$\Delta L e v$ & & -0.135 & 0.026 & 0.138 & -0.142 & -0.330 & -0.006 & 0.099 & -0.267 & -0.132 & -0.408 & 0.079 & 0.059 & 0.386 \\
\hline$\triangle D C o s t$ & -0.163 & & 0.034 & 0.068 & 0.078 & 0.137 & 0.170 & -0.184 & -0.005 & -0.080 & -0.083 & -0.219 & -0.030 & -0.119 \\
\hline$\Delta D M a t$ & 0.029 & -0.064 & & 0.046 & -0.125 & 0.029 & 0.043 & 0.083 & -0.081 & -0.101 & 0.047 & -0.020 & 0.008 & 0.029 \\
\hline Surprise & -0.041 & 0.191 & 0.056 & & -0.157 & 0.059 & 0.022 & -0.188 & -0.119 & 0.035 & -0.241 & 0.021 & -0.092 & 0.152 \\
\hline Predicted & -0.095 & -0.025 & -0.061 & -0.012 & & -0.056 & -0.011 & -0.096 & -0.011 & 0.013 & 0.276 & 0.128 & 0.037 & -0.154 \\
\hline AProfit & -0.236 & 0.091 & -0.041 & 0.107 & -0.243 & & 0.052 & -0.108 & 0.336 & 0.337 & -0.043 & -0.068 & -0.180 & -0.079 \\
\hline$\Delta R i s k$ & 0.098 & 0.079 & 0.085 & 0.006 & 0.125 & -0.017 & & 0.063 & -0.036 & -0.216 & -0.007 & -0.029 & -0.069 & -0.098 \\
\hline$\Delta$ Tang & 0.134 & -0.213 & 0.047 & -0.385 & -0.139 & -0.065 & 0.020 & & -0.005 & -0.029 & 0.053 & 0.021 & 0.419 & -0.167 \\
\hline$\Delta G r o w t h$ & -0.227 & -0.057 & -0.147 & -0.172 & -0.018 & 0.179 & 0.022 & 0.019 & & 0.122 & 0.015 & 0.060 & 0.029 & -0.291 \\
\hline$\Delta T a x$ & 0.022 & -0.143 & -0.117 & 0.026 & 0.140 & 0.025 & -0.025 & -0.016 & -0.042 & & 0.050 & 0.092 & -0.152 & 0.153 \\
\hline $\operatorname{Lev}_{t-1}$ & -0.432 & -0.006 & 0.025 & -0.174 & 0.225 & 0.086 & 0.031 & 0.064 & 0.011 & 0.036 & & -0.088 & 0.076 & -0.306 \\
\hline CrRate $_{t-1}$ & 0.080 & -0.228 & 0.004 & 0.000 & 0.093 & -0.119 & 0.004 & 0.091 & 0.085 & 0.012 & -0.002 & & 0.053 & 0.205 \\
\hline$\Delta A M a t$ & 0.302 & -0.271 & 0.019 & -0.357 & -0.057 & -0.065 & -0.104 & 0.413 & 0.070 & -0.280 & -0.071 & 0.158 & & -0.028 \\
\hline ASize & 0.388 & 0.024 & 0.045 & 0.191 & -0.166 & -0.017 & -0.011 & -0.127 & -0.322 & 0.052 & -0.272 & 0.151 & -0.002 & \\
\hline
\end{tabular}

Notes: Pearson's correlation coefficients are reported in the bottom left diagonal and Spearman's rank correlation coefficients are reported in the top right diagonal. Observations in bold are significant at the $10 \%$ or lower significance levels. Lev is the ratio of total financial debt over total assets. DCost is the average borrowing cost. DMat is the ratio of long-term financial over total financial debt. Surprise is the difference between the restated IFRS pension deficit at the beginning of the adoption year and the fitted value from regression 1 (Predicted). Profit is the return on operating assets (ROA) defined as operating income over total assets. Risk is the three-year standard deviation of ROA. Tang is defined as the ratio of fixed assets over total assets. Growth is next year's investing cash flows deflated by total assets and multiplied by minus one. Tax is taxes paid deflated by sales. CrRate is the company's S\&P credit rating. AMat is defined as (gross PPE / total assets $) \times($ gross PPE / depreciation expense $)+($ current assets / total assets $) \times($ current assets / cost of goods sold). Size is the natural logarithm of total assets. 
Table OA.B3: Regression Analysis of Pension Obligation's Impact on Debt - Excluding Companies with Public Debt.

Panel A: Leverage

\section{Excess Leverage}

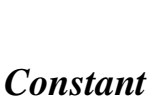

Surprise

Predicted

AProfit

ARisk

ATang

AGrowth

$\Delta \operatorname{Tax}$

CrRate $_{t-1}$

$\operatorname{Lev}_{t-1}$

N

$\mathrm{R}^{2}$
Low Credit Score

(2)

0.043* $^{*}$

$(0.024)$

$-1.102 * * *$

$(0.369)$

$-1.785$

(1.421)

$-0.095$

(0.104)

0.164

(0.241)

$0.883 * *$

$(0.338)$

-0.094*

$(0.055)$

0.727

$(0.492)$

0.001

$(0.002)$

$-\mathbf{0 . 1 0 5 *}$

(0.060)
High Merton Default Probability

\begin{tabular}{c}
$\mathbf{( 3 )}$ \\
\hline 0.025 \\
$(0.024)$ \\
$\mathbf{- 0 . 9 7 7 * * *}$ \\
$(0.347)$ \\
-0.475 \\
$(1.150)$ \\
-0.045 \\
$(0.104)$ \\
-0.123 \\
$(0.271)$
\end{tabular}

$0.793 * *$

(0.298)

$-0.163$

(0.106)

0.099

(0.503)

0.001

$(0.002)$

$-\mathbf{0 . 1 0 3 *}$

(0.059)

45
0.56

54

0.49 
Panel B: Cost of Debt

Excess Leverage

(1)

Constant

Surprise

Predicted

AProfit

ARisk

ATang

AGrowth

$\Delta \operatorname{Tax}$

CrRate $_{t-1}$
Low Credit Score

(2)

$0.047^{* *}$

(0.019)

0.668 **

$(0.296)$

1.468

(1.139)

0.083

$(0.083)$

$0.527 * * *$

(0.193)

$-0.168$

$(0.271)$

0.052

(0.044)

$\mathbf{- 0 . 7 1 8 *}$

$(0.395)$

$-0.002$

(0.002)

-0.168 ***

(0.048)
High Merton Default

Probability

(3)

$\mathbf{0 . 0 2 8}^{* *}$

(0.013)

$0.810 * * *$

(0.188)

0.119

(0.623)

$-0.074$

(0.057)

0.646 ****

(0.147)

$-0.136$

(0.161)

0.009

(0.058)

$-0.234$

$(0.273)$

$-0.002 *$

(0.001)

$-0.043$

(0.032)

\begin{tabular}{lccc}
\hline $\mathrm{N}$ & 60 & 45 & 54 \\
$\mathrm{R}^{2}$ & 0.69 & 0.49 & 0.56 \\
\hline
\end{tabular}

Notes: To ensure the results are not simply driven by companies with public debt, we repeat the main analysis excluding such companies.

Surprise is the difference between the restated IFRS pension deficit at the beginning of the adoption year and the fitted value from regression 1 (Predicted). Profit is the return on operating assets (ROA) defined as operating income over total assets. Risk is the three-year standard deviation of ROA. Tang is defined as the ratio of fixed assets over total assets. Growth is next year's investing cash flows deflated by total assets and multiplied by minus one. Tax is taxes paid deflated by sales. CrRate is the company's S\&P credit rating. Levt-1 is lagged leverage. Standard errors are reported in parentheses. ${ }^{* *}, * *, *$ indicate significance at $1 \%, 5 \%$, and $10 \%$ level, respectively.

The results reported in this table are consistent with the main findings. 
Table OA.B4: Regression Analysis of Pension Obligation's Impact on Debt - Excluding Companies Involved in M\&As.

Panel A: Leverage

Excess Leverage $\quad$ Low Credit Score $\begin{gathered}\text { High Merton Default } \\ \text { Probability }\end{gathered}$

\begin{tabular}{|c|c|c|c|}
\hline & (1) & (2) & (3) \\
\hline \multirow[t]{2}{*}{ Constant } & 0.042 & $-1.141 * *$ & $-1.415 * * *$ \\
\hline & $(0.038)$ & $(0.433)$ & $(0.404)$ \\
\hline \multirow[t]{2}{*}{ Surprise } & $-1.775 * * *$ & $-1.141^{* * *}$ & $-1.415 * * *$ \\
\hline & $(0.399)$ & $(0.433)$ & $(0.404)$ \\
\hline \multirow[t]{2}{*}{ Predicted } & -1.893 & -1.553 & -0.416 \\
\hline & (1.147) & (1.611) & (1.541) \\
\hline \multirow[t]{2}{*}{$\Delta$ Profit } & -0.083 & 0.002 & 0.003 \\
\hline & $(0.101)$ & $(0.117)$ & $(0.123)$ \\
\hline \multirow[t]{2}{*}{$\Delta R i s k$} & $0.797 * * *$ & $0.560 * *$ & $0.485^{*}$ \\
\hline & $(0.209)$ & $(0.225)$ & $(0.243)$ \\
\hline \multirow[t]{2}{*}{$\Delta$ Tang } & 0.294 & $0.845 * *$ & 0.517 \\
\hline & $(0.395)$ & $(0.411)$ & $(0.360)$ \\
\hline \multirow[t]{2}{*}{ AGrowth } & -0.213 & $-0.194 * *$ & -0.186 \\
\hline & $(0.131)$ & $(0.075)$ & $(0.138)$ \\
\hline \multirow[t]{2}{*}{$\Delta T a x$} & -0.790 & 0.398 & -0.050 \\
\hline & $(0.562)$ & $(0.681)$ & $(0.606)$ \\
\hline \multirow[t]{2}{*}{ CrRate $_{t-1}$} & 0.002 & $0.054 *$ & 0.041 \\
\hline & $(0.002)$ & $(0.029)$ & $(0.030)$ \\
\hline \multirow[t]{2}{*}{$L e v_{t-1}$} & $-0.179 * *$ & $-0.260 * * *$ & $-0.221 * * *$ \\
\hline & $(0.067)$ & $(0.060)$ & $(0.066)$ \\
\hline $\mathrm{N}$ & 44 & 39 & 46 \\
\hline $\mathrm{R}^{2}$ & 0.65 & 0.67 & 0.55 \\
\hline
\end{tabular}


Panel B: Cost of Debt

\section{Excess Leverage $\quad$ Low Credit Score $\quad \begin{gathered}\text { High Merton } \\ \text { Default Probability }\end{gathered}$}

(1) (2) (3)

Constant

$-0.032 *$

0.020

$-0.005$

$(0.014)$

$(0.022)$

$(0.011)$

Surprise

$0.976 * * *$

0.676*

$0.950 * * *$

$(0.149)$

$(0.332)$

$(0.147)$

Predicted

0.525

1.269

$-0.430$

(0.428)

(1.234)

(0.561)

AProfit

$-0.037$

0.046

$-0.060$

(0.038)

(0.089)

(0.045)

ARisk

0.016

0.044

0.108

(0.078)

(0.172)

(0.089)

0.005

$-0.230$

$-0.012$

(0.148)

(0.315)

$(0.131)$

0.022

0.072

0.008

(0.049)

(0.057)

(0.050)

$\Delta \operatorname{Tax}$

-0.371 *

$-1.319 * *$

$\mathbf{- 0 . 6 0 3} * * *$

$(0.210)$

$(0.522)$

$(0.221)$

CrRate $_{t-1}$

0.001

$-0.001$

$-0.001$

(0.001)

(0.002)

$(0.001)$

0.060 **

$-0.072$

0.045*

(0.025)

(0.046)

(0.024)

\begin{tabular}{lccc}
\hline $\mathrm{N}$ & 44 & 39 & 46 \\
$\mathrm{R}^{2}$ & 0.69 & 0.42 & 0.65 \\
\hline
\end{tabular}

Notes: Mergers and acquisitions are often financed by debt and to ensure that the results are not driven by such changes in the reporting group, we repeat the main analysis excluding companies that either acquired or sold subsidiaries in 2005 .

Surprise is the difference between the restated IFRS pension deficit at the beginning of the adoption year and the fitted value from regression 1 (Predicted). Profit is the return on operating assets (ROA) defined as operating income over total assets. Risk is the three-year standard deviation of ROA. Tang is defined as the ratio of fixed assets over total assets. Growth is next year's investing cash flows deflated by total assets and multiplied by minus one. Tax is taxes paid deflated by sales. CrRate is the company's S\&P credit rating. Lev $v_{t-1}$ is lagged leverage. Standard errors are reported in parentheses. $* * *, * *, *$ indicate significance at $1 \%, 5 \%$, and $10 \%$ level, respectively.

The results reported in this table are consistent with the main findings. 
Table OA.B5: Regression Analysis of Pension Obligation's Impact on Leverage Ranking.

Panel A: Leverage

\section{Excess Leverage $\quad$ Low Credit Score $\begin{gathered}\text { High Merton } \\ \text { Default Probability }\end{gathered}$}

Constant

Rank

Profit

Risk

Tang

AGrowth

$\Delta \operatorname{Tax}$

CrRate $_{t-1}$

$\begin{array}{lc} & 0.002 \\ \text { Lev }_{t-1} & (0.002) \\ & \mathbf{- 0 . 1 7 7 * *} \\ & (0.069)\end{array}$

\section{(1)}

\begin{tabular}{c}
$\mathbf{( 1 )}$ \\
\hline 0.035 \\
$(0.041)$
\end{tabular}

$-0.000$

$(0.000)$

$-0.157$

(0.110)

0.376

$(0.252)$

0.428

(0.330)

$-0.099$

(0.072)

0.169

(0.413)
(2)

$\frac{(2)}{0.044}(0.032)$

\begin{tabular}{c}
$(\mathbf{3})$ \\
\hline 0.019 \\
$(0.030)$
\end{tabular}

$-0.000$

$-0.000$

$(0.000)$

$-0.102$

(0.101)

0.283

$(0.245)$

0.730 **

$(0.308)$

$-0.068$

(0.121)

0.527

(0.506)

0.004

(0.002)

$\mathbf{- 0 . 1 7 9 * * * * ~}$

(0.057)

\begin{tabular}{lccc}
\hline $\mathrm{N}$ & 74 & 54 & 62 \\
$\mathrm{R}^{2}$ & 0.24 & 0.37 & 0.35 \\
\hline
\end{tabular}


Panel B: Cost of Debt

\section{Excess Leverage $\quad$ Low Credit Score $\quad \begin{gathered}\text { High Merton } \\ \text { Default Probability }\end{gathered}$}

(1) (2)

(3)

\section{Constant}

0.000
$(0.015)$

$0.051 * *$

0.026

0.000

$(0.021)$

$(0.016)$

Rank

0.000

$-0.000$

$-0.000$

$(0.000)$

$(0.000)$

(0.000)

MProfit

$-0.014$

0.047

0.009

$(0.039)$

(0.068)

(0.056)

MRisk

0.029

0.227

0.204

(0.081)

$(0.159)$

(0.136)

ATang

-0.243 **

-0.457 *

-0.375 **

(0.120)

(0.247)

(0.172)

$-0.016$

0.030

0.016

(0.029)

(0.046)

(0.067)

$\Delta \operatorname{Tax}$

$-0.050$

-0.647 *

-0.489*

(0.126)

(0.349)

(0.282)

$-0.000$

$-0.002$

$-0.002$

CrRate $_{t-1}$

(0.001)

$(0.002)$

(0.001)

0.014

-0.075 *

$-0.030$

(0.027)

(0.038)

(0.032)

\begin{tabular}{lccc}
\hline $\mathrm{N}$ & 74 & 54 & 62 \\
$\mathrm{R}^{2}$ & 0.10 & 0.27 & 0.21 \\
\hline
\end{tabular}

Notes: To ensure that the Surprise measure is not just a proxy for the pension deficit's size, we regress changes in leverage (Panel A) and cost of debt (Panel B) of mandatory adopters on their ranking in terms of the size of their 2004 pension plan deficit (Rank).

Profit is the return on operating assets (ROA) defined as operating income over total assets. Risk is the threeyear standard deviation of ROA. Tang is defined as the ratio of fixed assets over total assets. Growth is next year's investing cash flows deflated by total assets and multiplied by minus one. Tax is taxes paid deflated by sales. CrRate is the company's S\&P credit rating. Lev $v_{t-1}$ is lagged leverage. Standard errors are reported in parentheses. $* * *, * *, *$ indicate significance at $1 \%, 5 \%$, and $10 \%$ level, respectively.

The results reported in this table confirm that the main results are not driven by the size of the pension deficit. 
Table OA.B6: Regression Analysis of Pension Obligation's Impact on Debt - Reported Adjustment.

Panel A: Leverage

Excess Leverage

\section{Constant}

Surprise

TRSurprise

RRSurprise

AProfit

ARisk

ATang

AGrowth

$\Delta \operatorname{Tax}$

CrRate $_{t-1}$

\begin{tabular}{ccc}
$\mathbf{( 1 )}$ & $(\mathbf{2})$ & $\mathbf{( 3 )}$ \\
\hline 0.024 & 0.025 & 0.025 \\
$(0.035)$ & $(0.032)$ & $(0.033)$ \\
& $\mathbf{- 1 . 2 3 9 * * *}$ & $\mathbf{- 1 . 2 5 0 * * *}$ \\
& $(0.396)$ & $(0.448)$
\end{tabular}

$-0.375$

$(0.743)$

$(0.002)$

$\begin{array}{ccc} & & -0.057 \\ & & (1.106) \\ -0.162 & -0.113 & -0.115 \\ (0.110) & (0.104) & (0.109) \\ 0.380 & \mathbf{0 . 4 1 7} & \mathbf{0 . 4 1 9 *} \\ (0.252) & (0.236) & (0.241) \\ 0.456 & 0.065 & 0.064 \\ (0.327) & (0.326) & (0.329) \\ -0.102 & \mathbf{- 0 . 1 1 7} * & \mathbf{- 0 . 1 1 7} * \\ (0.073) & (0.068) & (0.068) \\ 0.214 & 0.255 & 0.258 \\ (0.431) & (0.388) & (0.394) \\ 0.001 & 0.001 & 0.001 \\ (0.002) & (0.002) & (0.002)\end{array}$

Low Credit Score

\begin{tabular}{ccc}
$\mathbf{( 4 )}$ & $\mathbf{( 5 )}$ & $\mathbf{( 6 )}$ \\
\hline $\mathbf{0 . 0 4 6}^{*}$ & 0.037 & 0.034 \\
$(0.026)$ & $(0.024)$ & $(0.029)$ \\
& $-\mathbf{1 . 1 5 4 * *}^{* *}$ & $\mathbf{- 1 . 1 2 3 * *}$ \\
& $(0.451)$ & $(0.477)$
\end{tabular}

$-0.735$

(0.735)

$\begin{array}{ccc} & & 0.411 \\ & & (1.834) \\ -0.076 & -0.023 & -0.014 \\ (0.104) & (0.101) & (0.110) \\ 0.366 & 0.352 & 0.349 \\ (0.245) & (0.230) & (0.233) \\ \mathbf{0 . 8 8 4 * *} & 0.524 & 0.519 \\ (0.380) & (0.390) & (0.395) \\ -0.067 & -0.091 & -0.091 \\ (0.068) & (0.065) & (0.066) \\ 0.769 & 0.715 & 0.691 \\ (0.543) & (0.487) & (0.504) \\ 0.001 & 0.002 & 0.002 \\ (0.003) & (0.003) & (0.003)\end{array}$

High Merton Default Probability

\begin{tabular}{ccc}
$\mathbf{( 7 )}$ & $(\mathbf{8})$ & $(\mathbf{9})$ \\
\hline 0.011 & 0.014 & 0.014 \\
$(0.025)$ & $(0.023)$ & $(0.025)$ \\
& $\mathbf{- 1 . 0 3 4 * * *}$ & $\mathbf{- 1 . 0 1 8 * *}$ \\
& $(0.378)$ & $(0.425)$ \\
-0.391 & & \\
$(0.643)$ & & \\
& & 0.115 \\
& & $(1.337)$ \\
-0.113 & -0.048 & -0.046 \\
$(0.100)$ & $(0.097)$ & $(0.102)$ \\
0.307 & 0.279 & 0.279 \\
$(0.242)$ & $(0.228)$ & $(0.230)$ \\
$\mathbf{0 . 7 4 4 * *}$ & 0.440 & 0.443 \\
$(0.308)$ & $(0.309)$ & $(0.313)$ \\
-0.051 & -0.088 & -0.087 \\
$(0.118)$ & $(0.112)$ & $(0.114)$ \\
0.462 & 0.445 & 0.441 \\
$(0.495)$ & $(0.464)$ & $(0.470)$ \\
0.003 & $\mathbf{0 . 0 0 4} *$ & $\mathbf{0 . 0 0 4} *$ \\
$(0.002)$ & $(0.002)$ & $(0.002)$
\end{tabular}




\begin{tabular}{|c|c|c|c|c|c|c|c|c|c|}
\hline $\operatorname{Lev}_{t-1}$ & $\begin{array}{c}\mathbf{- 0 . 1 6 9 * *} \\
(0.069)\end{array}$ & $\begin{array}{c}\mathbf{- 0 . 1 8 0} * * * \\
(0.064)\end{array}$ & $\begin{array}{c}\mathbf{- 0 . 1 8 0} * * * \\
(0.066)\end{array}$ & $\begin{array}{c}\mathbf{- 0 . 2 1 8} * * * \\
(0.059)\end{array}$ & $\begin{array}{c}-\mathbf{- 0 . 2 1 6} * * * \\
(0.054)\end{array}$ & $\begin{array}{c}\mathbf{- 0 . 2 2 0} * * * \\
(0.058)\end{array}$ & $\begin{array}{c}\mathbf{- 0 . 1 7 6} * * * \\
(0.057)\end{array}$ & $\begin{array}{c}\mathbf{- 0 . 1 9 9} * * * \\
(0.054)\end{array}$ & $\begin{array}{c}\mathbf{- 0 . 2 0 1} * * * \\
(0.057)\end{array}$ \\
\hline $\mathrm{N}$ & 74 & 74 & 74 & 54 & 54 & 54 & 62 & 62 & 62 \\
\hline $\mathrm{R}^{2}$ & 0.23 & 0.33 & 0.33 & 0.38 & 0.45 & 0.45 & 0.35 & 0.43 & 0.43 \\
\hline AIC & -174.40 & -184.51 & -182.52 & -116.70 & -122.83 & -120.89 & -147.57 & -155.33 & -153.34 \\
\hline
\end{tabular}


Panel B: Cost of Debt

Excess Leverage

\section{Constant}

Surprise

TRSurprise

RRSurprise

MProfit

ARisk

ATang

AGrowth

$\Delta \operatorname{Tax}$

CrRate $_{t-1}$

$\operatorname{Lev}_{t-1}$

\begin{tabular}{ccc}
$\mathbf{( 1 )}$ & $\mathbf{( 2 )}$ & $\mathbf{( 3 )}$ \\
\hline-0.016 & -0.008 & -0.012 \\
$(0.012)$ & $(0.009)$ & $(0.010)$ \\
& $\mathbf{0 . 8 7 6 * * *}$ & $\mathbf{0 . 9 5 1 * * *}$ \\
& $(0.117)$ & $(0.131)$
\end{tabular}

$0.879 * * *$

$(0.258)$

$\begin{array}{ccc} & & 0.410 \\ & & (0.324) \\ -0.011 & -0.043 & -0.032 \\ (0.038) & (0.031) & (0.032) \\ 0.025 & 0.010 & -0.005 \\ (0.088) & (0.070) & (0.071) \\ \mathbf{- 0 . 2 9 1 * *} & -0.087 & -0.079 \\ (0.114) & (0.097) & (0.096) \\ -0.012 & -0.011 & -0.011 \\ (0.025) & (0.020) & (0.020) \\ \mathbf{- 0 . 4 2 0 * * *} & \mathbf{- 0 . 3 4 7 * * *} & \mathbf{- 0 . 3 6 6 * * *} \\ (0.150) & (0.115) & (0.116) \\ 0.001 & 0.000 & 0.000 \\ (0.001) & (0.001) & (0.001) \\ 0.014 & 0.023 & 0.018 \\ (0.024) & (0.019) & (0.019)\end{array}$

Low Credit Score

\begin{tabular}{ccc}
$\mathbf{( 4 )}$ & $(\mathbf{5})$ & $(\mathbf{6})$ \\
\hline $\mathbf{0 . 0 4 4} * *$ & $\mathbf{0 . 0 5 0} * * *$ & \\
$(0.017)$ & $(0.016)$ & \\
& $\mathbf{0 . 6 9 6} * *$ & $\mathbf{0 . 7 4 8} * *$ \\
& $(0.294)$ & $(0.309)$ \\
0.506 & & \\
$(0.473)$ & & \\
& & 0.688 \\
& & $(1.189)$ \\
$\mathbf{0 . 0 4 6}$ & 0.014 & 0.030 \\
$(0.067)$ & $(0.065)$ & $(0.072)$ \\
0.210 & 0.220 & 0.214 \\
$(0.158)$ & $(0.150)$ & $(0.151)$ \\
$\mathbf{- 0 . 4 1 9 *}$ & -0.207 & -0.216 \\
$(0.245)$ & $(0.254)$ & $(0.256)$ \\
0.040 & 0.054 & 0.054 \\
$(0.044)$ & $(0.042)$ & $(0.043)$ \\
$\mathbf{- 0 . 7 8 5} * *$ & $\mathbf{- 0 . 7 3 8 * *}$ & $\mathbf{- 0 . 7 7 8} * *$ \\
$(0.350)$ & $(0.317)$ & $(0.327)$ \\
-0.002 & -0.003 & -0.003 \\
$(0.002)$ & $(0.002)$ & $(0.002)$ \\
$\mathbf{- 0 . 0 8 7 * *}$ & $\mathbf{- 0 . 0 8 7 * *}$ & $\mathbf{- 0 . 0 9 4 * *}$ \\
$(0.038)$ & $(0.035)$ & $(0.038)$
\end{tabular}

High Merton Default Probability

\begin{tabular}{|c|c|c|}
\hline$(7)$ & (8) & (9) \\
\hline 0.017 & 0.020* & 0.017 \\
\hline \multirow[t]{3}{*}{$(0.013)$} & $(0.012)$ & $(0.013)$ \\
\hline & $0.766 * * *$ & $0.852 * * *$ \\
\hline & $(0.197)$ & $(0.220)$ \\
\hline \multirow{2}{*}{\multicolumn{3}{|c|}{$\begin{array}{c}\mathbf{0 . 6 1 3}^{*} \\
(0.347)\end{array}$}} \\
\hline & & \\
\hline & & 0.622 \\
\hline & & $(0.692)$ \\
\hline 0.007 & -0.041 & -0.027 \\
\hline$(0.054)$ & $(0.051)$ & $(0.053)$ \\
\hline 0.212 & $0.229 *$ & $0.226 *$ \\
\hline$(0.131)$ & $(0.119)$ & $(0.119)$ \\
\hline$-0.308 *$ & -0.118 & -0.102 \\
\hline$(0.166)$ & $(0.161)$ & $(0.162)$ \\
\hline 0.021 & 0.047 & 0.051 \\
\hline (0.064) & (0.059) & $(0.059)$ \\
\hline$-0.520 *$ & $-0.492 * *$ & $-0.510 * *$ \\
\hline$(0.267)$ & $(0.242)$ & $(0.244)$ \\
\hline-0.002 & $-0.002 *$ & $-0.002 *$ \\
\hline$(0.001)$ & $(0.001)$ & $(0.001)$ \\
\hline-0.033 & -0.015 & -0.023 \\
\hline$(0.031)$ & $(0.028)$ & $(0.030)$ \\
\hline
\end{tabular}




\begin{tabular}{|c|c|c|c|c|c|c|c|c|c|}
\hline $\mathrm{N}$ & 74 & 74 & 74 & 54 & 54 & 54 & 62 & 62 & 62 \\
\hline $\mathrm{R}^{2}$ & 0.31 & 0.56 & 0.57 & 0.29 & 0.35 & 0.36 & 0.26 & 0.39 & 0.40 \\
\hline AIC & -330.68 & -364.31 & -364.13 & -164.25 & -169.24 & -167.65 & -224.06 & -236.03 & -234.99 \\
\hline
\end{tabular}

Notes: Some of the mandatory adopters in the sample recognized a pension deficit on their balance sheet prior to IFRS adoption, even though they were not complying with the IAS 19 valuation requirements. To confirm that the markets' estimation of pension deficit prior to mandatory IAS 19 adoption incorporated information beyond any deficits already recognized by non-early adopting companies, we examine separately the "total reported surprise" (TRSuprise) defined as the difference between the 2004 recognized pension deficit under local GAAP (if any) and the IFRS adjusted 2004 pension deficit; Surprise defined as the difference between the restated IFRS pension deficit at the beginning of the adoption year and the fitted value from regression 1 (Predicted); and RRSurprise defined as the highest between the value of 0 and the difference between TRSurprise and Surprise.

Profit is the return on operating assets (ROA) defined as operating income over total assets. Risk is the three-year standard deviation of ROA. Tang is defined as the ratio of fixed assets over total assets. Growth is next year's investing cash flows deflated by total assets and multiplied by minus one. Tax is taxes paid deflated by sales. CrRate is the company's S\&P credit rating. Lev $v_{t-1}$ is lagged leverage. Standard errors are reported in parentheses. $* * *, * *, *$ indicate significance at $1 \%, 5 \%$, and $10 \%$ level, respectively.

Overall, the results are consistent with creditors looking beyond the statements of less transparent companies when estimating their hidden pension deficits. 
Table OA.B7: Regression Analysis of Pension Obligation's Impact on Debt - Early Adopters.

Panel A: Leverage

\section{Excess Leverage Low Credit Score}

Constant

Surprise

Predicted

DProfit

MRisk

$\Delta$ Tang

AGrowth

$\Delta \operatorname{Tax}$

CrRate $_{t-1}$

$\operatorname{Lev}_{t-1}$
(1) 0.064* (0.035) $-0.051$

$(0.358)$

$-0.691$

(0.874)

$-\mathbf{0 . 4 6 8} * * *$

(0.114)

$-0.024$

(0.329)

0.015

$(0.203)$

$-0.058$

(0.061)

0.171

(0.344)

0.001

(0.002)

$-0.257 * * *$

(0.064)
(2)

0.019

(0.029)

$-0.586$

(0.759)

1.565

(1.390)

$\mathbf{- 0 . 2 4 5 * *}$

(0.093)

$-0.081$

(0.241)

$-0.225$

$(0.273)$

$-0.057$

(0.061)

0.121

$(0.284)$

$-0.001$

(0.003)

$-0.177 * * *$

(0.063)
High Merton Default Probability

(3)

0.009

(0.038)

$-0.023$

$(0.721)$

$-0.218$

(1.403)

$\mathbf{- 0 . 3 5 8 * * *}$

$(0.122)$

0.098

(0.320)

$-0.199$

(0.317)

$-\mathbf{0 . 1 4 8 *}$

(0.085)

$-0.108$

(0.355)

0.002

(0.004)

$-0.161 * *$

(0.070)

\begin{tabular}{lccc}
\hline $\mathrm{N}$ & 79 & 59 & 53 \\
$\mathrm{R}^{2}$ & 0.37 & 0.25 & 0.37 \\
\hline
\end{tabular}


Panel B: Cost of Debt

\section{Excess Leverage $\quad$ Low Credit Score $\quad \begin{gathered}\text { High Merton } \\ \text { Default Probability }\end{gathered}$}

(1) (2)

(3)

Constant

0.007

$-0.006$

$0.024 * *$

$(0.009)$

$(0.024)$

$(0.009)$

Surprise

$-0.021$

$-0.306$

$-0.431 * *$

(0.088)

(0.619)

$(0.175)$

Predicted

0.290

$-0.198$

0.376

$(0.213)$

(1.135)

(0.341)

AProfit

$-0.026$

$-0.061$

$-0.034$

$(0.028)$

(0.076)

(0.030)

$-0.047$

$-0.505 * *$

$-0.081$

(0.080)

(0.197)

(0.078)

0.042

$-0.125$

$-0.089$

(0.049)

(0.223)

(0.077)

AGrowth

$-0.001$

0.042

$-0.045 * *$

(0.015)

(0.049)

(0.021)

$-0.115$

0.161

$-0.072$

(0.084)

$(0.232)$

(0.086)

CrRate $_{t-1}$

-0.001*

$-0.001$

$-0.002 * *$

(0.001)

(0.002)

(0.001)

$\operatorname{Lev}_{t-1}$

$-0.008$

0.064

$-0.032 *$

(0.016)

(0.052)

(0.017)

\begin{tabular}{lccc}
\hline $\mathrm{N}$ & 79 & 59 & 53 \\
$\mathrm{R}^{2}$ & 0.12 & 0.20 & 0.36 \\
\hline
\end{tabular}

Notes: To address omitted corellated variables concerns, we repeat the main analysis for early adopters. If the results are driven by correlated omitted variables, we would expect to find the same results for early adopters even though their pension plan deficits are known to the market before the year of our study.

Surprise is the difference between the restated IFRS pension deficit at the beginning of the adoption year and the fitted value from regression 1 (Predicted). Profit is the return on operating assets (ROA) defined as operating income over total assets. Risk is the three-year standard deviation of ROA. Tang is defined as the ratio of fixed assets over total assets. Growth is next year's investing cash flows deflated by total assets and multiplied by minus one. Tax is taxes paid deflated by sales. CrRate is the company's S\&P credit rating. $L e v_{t-1}$ is lagged leverage. Standard errors are reported in parentheses. $* * *$, **, * indicate significance at $1 \%, 5 \%$, and $10 \%$ level, respectively.

The results of this analysis confirm that the findings for mandatory adopters do not hold for early adopters. 
Table OA.B8: Regression Analysis of Pension Obligation's Impact on Leverage - Heckman Selection Model.

Panel A: Leverage Ratio

Excess Leverage

\begin{tabular}{|c|c|c|c|c|c|c|}
\hline & 1st stage & 2nd stage & 1st stage & 2nd stage & 1st stage & 2nd stage \\
\hline \multirow[t]{2}{*}{ Constant } & 0.427 & 0.048 & 0.204 & $0.102 * *$ & 0.197 & 0.167 \\
\hline & (0.393) & $(0.041)$ & (0.306) & $(0.049)$ & $(0.331)$ & $(0.376)$ \\
\hline \multirow[t]{2}{*}{ SegRep } & $-0.644 * *$ & & $-1.011 * * *$ & & -0.162 & \\
\hline & $(0.289)$ & & $(0.388)$ & & $(0.375)$ & \\
\hline \multirow[t]{2}{*}{ Surprise } & & $-1.273 * * *$ & & $-1.113 * * *$ & & -0.994 \\
\hline & & $(0.367)$ & & $(0.390)$ & & $(0.737)$ \\
\hline \multirow[t]{2}{*}{ Predicted } & & -1.007 & & -1.442 & & -0.835 \\
\hline & & (0.903) & & (1.325) & & (2.208) \\
\hline \multirow[t]{2}{*}{ AProfit } & 0.934 & -0.164 & 0.797 & -0.132 & 1.631 & -0.279 \\
\hline & (1.367) & (0.105) & (1.157) & $(0.120)$ & (1.373) & $(0.571)$ \\
\hline \multirow[t]{2}{*}{ ARisk } & -3.989 & $0.514 * *$ & -4.427 & $0.599 * *$ & $-6.180 * *$ & 1.003 \\
\hline & (3.157) & $(0.257)$ & (2.704) & $(0.284)$ & $(3.138)$ & (1.892) \\
\hline \multirow[t]{2}{*}{ STang } & 4.553 & -0.030 & 4.168 & 0.397 & 1.232 & 0.282 \\
\hline & (3.015) & $(0.328)$ & (3.604) & (0.389) & (3.594) & $(0.830)$ \\
\hline \multirow[t]{2}{*}{$\Delta G r o w t h$} & 0.031 & $-0.121^{*}$ & -0.239 & -0.088 & $2.227 *$ & -0.378 \\
\hline & $(0.755)$ & (0.064) & $(0.692)$ & (0.066) & (1.249) & $(0.765)$ \\
\hline \multirow[t]{2}{*}{$\Delta \operatorname{Tax}$} & -4.599 & 0.344 & -5.704 & $1.163 * *$ & $-11.356^{* *}$ & 1.902 \\
\hline & (4.264) & $(0.396)$ & (4.299) & $(0.535)$ & $(5.175)$ & (3.725) \\
\hline \multirow[t]{2}{*}{ CrRate $_{t-1}$} & -0.021 & 0.002 & -0.019 & 0.002 & 0.016 & 0.002 \\
\hline & $(0.026)$ & $(0.002)$ & $(0.031)$ & (0.003) & $(0.032)$ & (0.008) \\
\hline \multirow[t]{2}{*}{$\operatorname{Lev}_{t-1}$} & -0.553 & $-0.168 * * *$ & -0.132 & $-0.173 * * *$ & -0.750 & -0.080 \\
\hline & $(0.773)$ & $(0.063)$ & $(0.619)$ & $(0.061)$ & (0.689) & $(0.301)$ \\
\hline \multirow[t]{2}{*}{$I M R$} & & -0.016 & & -0.070 & & -0.209 \\
\hline & & $(0.057)$ & & (0.058) & & $(0.533)$ \\
\hline $\mathrm{N}$ & 160 & 74 & 119 & 54 & 122 & 62 \\
\hline rho & & -0.261 & & -0.834 & & -1.000 \\
\hline
\end{tabular}


Panel B: Cost of Debt

Excess Leverage

\begin{tabular}{|c|c|}
\hline 1st stage & 2nd stage \\
\hline 0.419 & -0.001 \\
\hline$(0.391)$ & $(0.014)$ \\
\hline
\end{tabular}

$-0.596 * *$

(0.287)

Surprise

Predicted

MProfit $\quad 0.883$

(1.364)

$-4.100$

(3.153)

4.292

(3.004)

AGrowth

0.069

(0.755)

$\Delta \operatorname{Tax}$

$-4.919$

(4.270)

CrRate $_{t-1}$

$-0.026$

(0.026)

$\operatorname{Lev}_{t-1}$

$-0.507$

(0.768)
$0.881 * * *$

(0.108)

0.113

(0.268)

$-0.047$

(0.035)

0.046

(0.087)

$-0.118$

(0.103)

$-0.014$

(0.021)

$-0.298 * *$

(0.131)

0.001

(0.001)

0.027

$(0.020)$

$-0.0167$

(0.019)
Low Credit Score

\begin{tabular}{|c|c|}
\hline 1st stage & 2nd stage \\
\hline 0.199 & 0.043 \\
\hline$(0.306)$ & $(0.029)$ \\
\hline
\end{tabular}

$-1.018 * * *$

(0.383)
High Merton Default Probability

\begin{tabular}{ccc}
\hline 1st stage & & 2nd stage \\
\cline { 1 - 1 } 0.185 & & -0.068 \\
$(0.331)$ & & $(0.267)$ \\
-0.131 & & \\
$(0.374)$ & &
\end{tabular}

0.737

$(0.463)$

$-0.382$

(1.381)

(0.877)

0.071

$(0.402)$

(0.073)

0.190

(0.165)

$-0.203$

$(0.237)$

0.057

(0.039)

(0.693)

$-5.696$

(4.297)

$\mathbf{- 0 . 8 0 4} * *$

$(0.333)$

$-0.002$

(0.002)

(0.031)

$-0.113$

(0.618)

$-\mathbf{0 . 0 9 8}^{* * *}$

(0.036)

$-0.001$

(0.036)
$-0.174$

(1.295)

(3.129)

$-0.075$

(0.516)

(3.585)

0.208

(0.517)

(1.238)

$-1.345$

(2.695)

(5.198)

$-0.001$

(0.005)

$-0.069$

(0.195)

(0.687)

0.131

(0.375)

\begin{tabular}{|c|c|c|c|c|c|c|}
\hline $\mathrm{N}$ & 163 & 74 & 121 & 54 & 124 & 62 \\
\hline rho & & -0.739 & & -0.024 & & 1 \\
\hline
\end{tabular}

Notes: To address the potential endogeneity in the adoption decision, we re-run the analysis employing a Heckman selection model using the provision of segment-related information in 2004 as the exogenous instrument.

SegRep is a dichotomous variable taking the value of 1 if the company provides information about depreciation expenses and total assets and/or liabilities in addition to basic segmented information (sales, operating income, and fixed assets). Surprise is the difference between the restated IFRS pension deficit at the beginning of the adoption year and the fitted value from regression 1 (Predicted). Profit is the return on operating assets (ROA) defined as operating income over total assets. Risk is the three-year standard deviation of ROA. Tang is defined as the ratio of fixed assets over total assets. Growth is next year's investing cash flows deflated by total assets and multiplied by minus one. Tax is taxes paid deflated by sales. CrRate is the company's S\&P credit rating. Levt-1 is lagged leverage. IMR is the Inverse Mills Ratio from the first-stage selection model. Standard errors are reported in parentheses. ***, **, * indicate significance at $1 \%, 5 \%$, and $10 \%$ level, respectively.

The results in this table are consistent with the main findings. 


\section{References}

Carrefour. (2004). 2004 Annual Report of Carrefour. Paris.

Carrefour. (2005). 2005 Annual Report of Carrefour. Paris.

Davydenko, S. A. \& Franks, J. R. (2008). Do bankruptcy codes matter? A study of defaults in France, Germany, and the U.K. The Journal of Finance, 63(2), pp. 565-608.

Depoers, F. (2000). A cost-benefit study of voluntary disclosure: Some empirical evidence from French listed companies. European Accounting Review, 9(2), pp. 245-263.

French Commercial Code (2006). French Commercial Code. Retrieved from: https://www.legifrance.gouv.fr/affichCode.do?cidTexte=LEGITEXT000005634379\&date Texte $=20061231$.

Fried Frank LLP. (2008). Underfunded pension liability: Lenders and buyers beware. New York, USA. Retrieved from: https://corpgov.law.harvard.edu/wpcontent/uploads/2008/11/ffhsjmemo1-underfunded-pension-liability.pdf.

Gaillot, L. (2008). Employees and bankruptcy proceedings - A French perspective. Retrieved from: https://www.iiiglobal.org/sites/default/files/laurentgaillot.pdf.

L'Oréal. (2004). 2004 Annual Report of L'Oréal. Paris.

L'Oréal. (2005). 2005 Annual Report of L'Oréal. Paris.

Orpea. (2004). 2004 Annual Report of Orpea. Paris.

Orpea (2005). 2005 Annual Report of Orpea. Paris.

Rauh, J. D. (2006). Investment and financing constraints: Evidence from the funding of corporate pension plans. The Journal of Finance, 61(1), pp. 33-71. 